\title{
A high-throughput virus-induced gene silencing protocol identifies genes involved in multi-stress tolerance
}

Venkategowda Ramegowda ${ }^{1,2,3+}$, Muthappa Senthil-kumar ${ }^{1,3+}$, Makarla Udayakumar ${ }^{2}$ and Kirankumar S Mysore ${ }^{1 *}$

\begin{abstract}
Background: Understanding the function of a particular gene under various stresses is important for engineering plants for broad-spectrum stress tolerance. Although virus-induced gene silencing (VIGS) has been used to characterize genes involved in abiotic stress tolerance, currently available gene silencing and stress imposition methodology at the whole plant level is not suitable for high-throughput functional analyses of genes. This demands a robust and reliable methodology for characterizing genes involved in abiotic and multi-stress tolerance.

Results: Our methodology employs VIGS-based gene silencing in leaf disks combined with simple stress imposition and effect quantification methodologies for easy and faster characterization of genes involved in abiotic and multi-stress tolerance. By subjecting leaf disks from gene-silenced plants to various abiotic stresses and inoculating silenced plants with various pathogens, we show the involvement of several genes for multi-stress tolerance. In addition, we demonstrate that VIGS can be used to characterize genes involved in thermotolerance. Our results also showed the functional relevance of NtEDS1 in abiotic stress, NbRBX1 and NbCTR1 in oxidative stress; NtRAR1 and NtNPR1 in salinity stress; NbSOS1 and NbHSP101 in biotic stress; and NtEDS1, NbETR1, NbWRKY2 and NbMYC2 in thermotolerance.
\end{abstract}

Conclusions: In addition to widening the application of VIGS, we developed a robust, easy and high-throughput methodology for functional characterization of genes involved in multi-stress tolerance.

Keywords: Stress tolerance, Drought, Salinity, Temperature stress, Nonhost resistance, Bacterial pathogens, VIGS, PTGS, Translational genomics

\section{Background}

Understanding the physiological and molecular mechanism of abiotic stress tolerance in plants is the foundation for developing stress tolerant plants. Transcriptome analyses have been successfully used to identify genes associated with abiotic stress responses. A large number of genes altered during various abiotic stresses have been identified through expression profiling, expressed sequence tags (ESTs), and cDNA library generated from various plant species [1-6]. However, identifying the functional significance of individual differentially expressed genes during abiotic stresses is a daunting task. It is

\footnotetext{
* Correspondence: ksmysore@noble.org

${ }^{\dagger}$ Equal contributors

${ }^{1}$ Plant Biology Division, The Samuel Roberts Noble Foundation, 2510 Sam Noble Pkwy., Ardmore, OK 73402, USA

Full list of author information is available at the end of the article
}

important to study the function of these stress-responsive genes not only to understand the mechanism of tolerance, but also for selecting candidate genes for improving the tolerance of susceptible species by genetic engineering.

Various functional genomics tools for gene overexpression or down-regulation have been developed for dissecting gene function [7]. Most commonly used gene knockout or knockdown approaches include ethyl methanesulfonate-induced point mutation [8], T-DNA insertion mutation [9], mutation by transposable element insertion [10], targeting induced local lesions in genomes [11] and gene silencing by RNAi [12]. Though these approaches have been widely and successfully used in functional analyses of genes, they have several disadvantages. For example, these approaches require generation of largescale mutant populations or transgenic plants to screen for mutation in a gene of interest, which is a tedious and

\section{() BioMed Central}


time consuming process. Mutation or insertion in a gene may not generate obvious phenotypes due to presence of gene families and gene duplications in plant genomes [13]. Virus-induced gene silencing (VIGS) is another functional genomics tool that avoids many of these limitations. In addition, VIGS can silence either an individual gene or multiple genes in a single plant and can also be used in a high-throughput manner to silence genes in multiple plants [14].

The basic principle of VIGS involves delivering viral RNA or DNA containing a partial sequence of a specific gene into plants [15]. Exogenous sequences are inserted into specific locations in the virus genome without destroying its infectivity [16]. The recombinant virus multiplies and spreads from the site of infection into new developing regions and triggers post-transcriptional gene silencing (PTGS; [17] [16]). VIGS has been used as both a forward and reverse genetics tool to study gene function in plants [18]. Currently about 35 different VIGS vectors are available for gene silencing [18], of which the Tobacco rattle virus (TRV)-based VIGS vector is the most widely used silencing vector [19].

VIGS has been used as a tool for dissecting mechanisms of abiotic stress tolerance. Genes involved in tolerance to stresses, namely drought [20-24], UV [25], salinity [23,26], hypoxia [27] and oxidative stress [23], have been effectively silenced by VIGS, and their relevance under respective stresses was studied by various research groups. However, VIGS has not been used to identify genes that play various roles in abiotic stress tolerance through a high-throughput forward genetics screening. Similarly, despite its potential, VIGS has not been used to study the role of a particular gene under multiple stresses at the same time. This is mainly due to lack of a suitable protocol to coincide respective abiotic stresses with VIGSmediated transient gene silencing as well as the absence of robust and easy methods to study the stress effect in silenced plants. Most of the methods currently used involve exposure of the whole plant to abiotic stress [24], which is a tedious process for large-scale screening. This scenario necessitates the requirement of high-throughput methodology to study stress effects on plants. In this manuscript, we describe a VIGS-based high-throughput methodology to study abiotic stress tolerance. Using this methodology, apart from confirming the role of several genes in biotic or abiotic stress tolerance which has been previously reported, we identified few genes that play a role in multi-stress tolerance.

\section{Results and discussion}

VIGS can continue to occur in excised leaf disks for more than six weeks

To determine whether the progression of VIGS can continue in excised leaf disks as it does in the whole plant, the leaf disks were collected from TRV::NbPDS-, TRV:: $\mathrm{NbChlH-}$, and vector control plants at 8 days postinoculation (dpi) and incubated on MS medium. Similar treatment was also done for leaf disks from the noninoculated wild-type plants. The progression of gene silencing was monitored until $16 \mathrm{dpi}$. Agrobacterium-mediated virus construct delivery into plant cell and initiation of VIGS is expected to take at least a week's time. We, therefore, expected to see a silencing phenotype two weeks after TRV inoculation. Silencing of $\mathrm{NbPDS}$ and $\mathrm{NbChlH}$ genes in plants produces photobleaching and yellowing of leaves, respectively [28]. At $8 \mathrm{dpi}$, all the leaf disks were green, and the expected silencing phenotype started from $14 \mathrm{dpi}$ and continued for few weeks (Figure 1A).

VIGS of both NbPDS and NbChlH genes occurred in leaf disks incubated both on MS medium and callus induction medium (CIM). In addition, uniform silencing persisted even up to $40 \mathrm{dpi}$. As expected, the silencing did not occur in vector control and non-inoculated wild-type plants (Figure 1B, upper panel). RT-PCR analysis of leaf disks maintained on CIM showed reduced transcript levels of silenced marker genes. All through the observed period, TRV was present in the leaf disks as indicated by PCR amplification of gene encoding coat protein (CP) (Figure 1B, lower panel). The presence of VIGS vector is essential for gene silencing by RNA viruses [29]. Conclusively, our results showed that gene silencing can occur in the excised leaf disks. These results are consistent with previous studies that used detached leaves from VIGS plants to study Agrobacterium-mediated plant transformation [30] and stress assays [24,26,31,32].

\section{Silencing genes involved in abiotic stress tolerance in excised leaf disks and their responses to various stresses}

One of the objectives of this study was to develop a highthroughput protocol for identification and functional characterization of genes involved in imparting stress tolerance. We selected 28 Nicotiana benthamiana or tobacco homologous genes that were shown to be differentially expressed during various stress responses in different plant species (Table 1). GENEVESTIGATOR [33] data showed corresponding Arabidopsis homologs of these genes were also induced under respective stresses in Arabidopsis (data not shown). Fragments (300-580 bp) of these genes were individually cloned into $p T R V 2$ VIGS vector [19], and the viral constructs were used to silence individual corresponding genes in $N$. benthamiana as described previously [28,32,34]. Leaf disks were punched from the upper newly developed leaves at $20 \mathrm{dpi}$ and the excised tissues were exposed to different abiotic stresses by incubating them on MS medium or CIM supplemented with respective stress-inducing agents. Responses of the gene-silenced leaf disks to individual abiotic stresses are given below. 

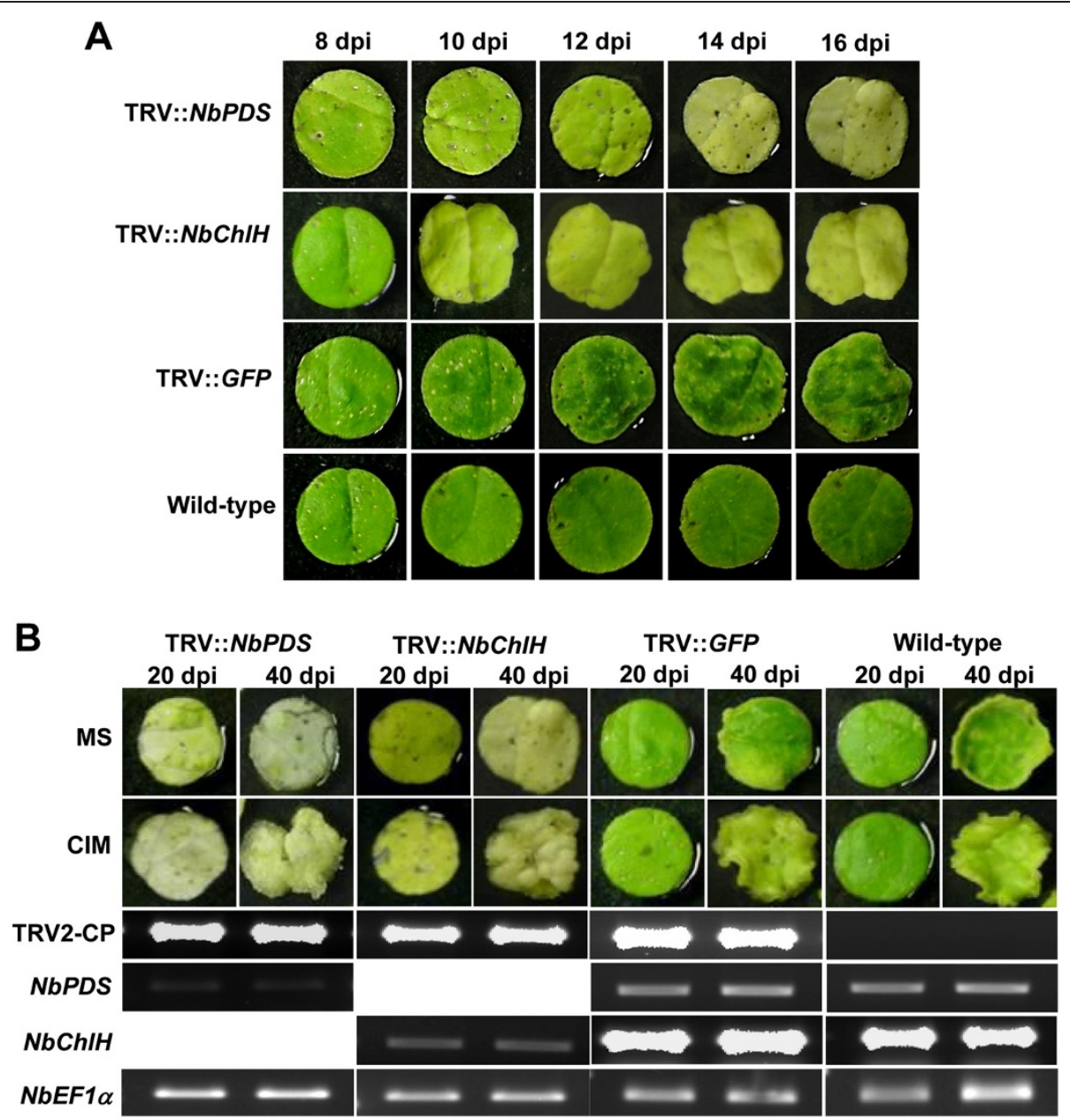

Figure 1 Progression and persistence of VIGS in excised leaf disks. Three-week-old N. benthamiana plants were inoculated with Agrobacterium carrying TRV::NbPDS and TRV::NbChIH constructs and grown in the greenhouse along with TRV::GFP (vector control) and wild-type non-inoculated plants. A) Leaf disks were collected from upper non-inoculated newly developed leaves at $8 \mathrm{dpi}$ and incubated on MS medium. Since silencing of $\mathrm{NbPDS}$ and $\mathrm{NbChlH}$ genes in leaves is expected to produce discoloration, change in phenotype (from dark green to white or yellowing) was monitored and photographs were taken at two-day intervals. B) Leaf disks were collected from upper non-inoculated newly developed leaves from silenced plants at $20 \mathrm{dpi}$ and incubated on MS medium and CIM. Persistence of silencing phenotype (white or yellow) was monitored for 20 more days, and photographs were taken at 20 and $40 \mathrm{dpi}$. The upper panel shows the respective phenotype and the lower panel shows RT-PCR that was performed using first-strand cDNA as a template, synthesized from total RNA $(2 \mu \mathrm{g})$ primed by oligo-(dT) $)_{15}$, with 30 PCR cycles. Plates containing leaf disks were maintained under day/night period of $16 \mathrm{~h} / 8 \mathrm{~h}$ at light intensity of $100 \mu \mathrm{mol} \mathrm{m} \mathrm{m}^{-2}$ in both cases. NbPDS, N. benthamiana phytoene desaturase; NbChIH, N. benthamiana Mg-chelatase H subunit; GFP, green fluorescent protein; dpi, days post-inoculation; MS, Murashige and Skoog medium; CIM, callus induction medium; TRV2-CP, Tobacco rattle virus RNA2 coat protein; EF1a, Elongation factor-1 alpha as loading control.

\section{Dehydration and osmotic stress}

Dehydration stress response was studied by estimating the rate of water loss during dehydration treatment. Detached leaf drying assay was reported to be an easy assay for testing large numbers of plants for their dehydration stress avoidance [60]. By utilizing this assay, we studied the responses of gene-silenced plants to dehydration stress by evaluating the decline in fresh weight of detached leaves. Among 28 different gene-silenced plants, leaves from $N b G S T-, N b R B X 1$ - and $N b M Y B 1-$ silenced plants showed a $10-20 \%$ increase in water loss over vector control plants at $6 \mathrm{~h}$ (Figure 2A). Our results agree with previous reports that GST, RBX1 and MYB1 genes are involved in water deficit stress tolerance $[50,61,62]$ and indicate that our method can be used to identify genes involved in dehydration stress avoidance. Interestingly, leaves harvested from NtEDS1-silenced plants showed about $40 \%$ increase in water loss over the control at $6 \mathrm{~h}$ after detachment from plants (Figure 2A). This data indicate that the EDS1 gene, whose function was implicated mainly in disease resistance [63], may also function in dehydration avoidance. 
Table 1 List of genes associated with various abiotic stresses and disease resistance used in the study

\begin{tabular}{|c|c|c|c|c|}
\hline & Gene & Functional annotation of gene fragments & NCBI GenBank accession \# & Reference* \\
\hline \multicolumn{5}{|c|}{ Salinity tolerance } \\
\hline 1 & NbSOS1 & Salt overly sensitive $1(\mathrm{Na}+/ \mathrm{H}+$ antiporter $)$ & JK739016 & {$[35]$} \\
\hline \multicolumn{5}{|c|}{ Oxidative stress tolerance } \\
\hline 2 & NbAPX3 & Ascorbate peroxidase 3 & JK739005 & {$[36]$} \\
\hline 3 & NbGST1 & Glutathione S-transferase 1 & JK739012 & {$[37,38]$} \\
\hline 4 & NbCAT3 & Catalase isozyme 3 & JK739008 & {$[39]$} \\
\hline 5 & NbDHAR1 & Dehydroascorbate reductase 1 & JK739010 & {$[40]$} \\
\hline 6 & $N b G P X 2$ & Glutathione peroxidase 2 & JK739011 & {$[38,41]$} \\
\hline 7 & NbFER2 & Ferritin 2 & JK739023 & {$[42]$} \\
\hline \multicolumn{5}{|c|}{ High or low temperature stress tolerance } \\
\hline 8 & NbHSP101 & $101 \mathrm{kDa}$ heat shock protein & JK739013 & {$[43]$} \\
\hline 9 & NbBIP5 & Binding protein 5 & JK739006 & {$[44]$} \\
\hline \multicolumn{5}{|c|}{ Water deficit stress tolerance } \\
\hline 10 & NbP5CS1 & Delta-1-pyrroline-5-carboxylate synthetase 1 & JK739014 & {$[45]$} \\
\hline 11 & $N b C B L 1$ & Calcineurin B-like protein 1 & JK739022 & {$[46,47]$} \\
\hline 12 & NbMYC2 & MYC-related transcription factor 2 & JK739021 & {$[48]$} \\
\hline 13 & NbGBP16 & Putative monomeric G-protein 16 & JK739018 & [49] \\
\hline 14 & NbRBX1 & Ring box 1 like protein & JK739020 & {$[50]$} \\
\hline \multicolumn{5}{|c|}{ Disease resistance } \\
\hline 15 & NbPAL1 & Phenylalanine ammonia-lyase 1 & JK739025 & {$[51]$} \\
\hline 16 & NtEDS1 & Enhanced disease susceptibility 1 & AF480489 & {$[52]$} \\
\hline 17 & NtNPR1 & Non-expresser of pathogenesis related gene 1 & AF480488 & [53] \\
\hline 18 & NtRAR1 & Required for Mla12 resistance 1 & AF480487 & {$[54]$} \\
\hline 19 & NbADR1 & Activated disease resistance 1 & JK739004 & {$[55]$} \\
\hline \multicolumn{5}{|c|}{ Other genes up- or down-regulated by various stresses } \\
\hline 20 & NbMC & Metacaspase type II & JK739007 & {$[56]$} \\
\hline 21 & NbCYCD2 & Cyclin D2.1 protein & JK739009 & - \\
\hline 22 & NbCTR1 & Constitutive triple response 1 -like protein kinase & JK739017 & {$[57]$} \\
\hline 23 & NbWRKY1 & WRKY DNA-binding protein 1 & AY547498 & {$[57]$} \\
\hline 24 & NtMEK1 & MAP kinase/ERK kinase 1 & AJ302651 & {$[57]$} \\
\hline 25 & NbWRKY2 & WRKY DNA-binding protein 2 & AY547495 & {$[57]$} \\
\hline 26 & NbETR1 & Ethylene response 1 & EF203416 & {$[58]$} \\
\hline 27 & NbFLS1 & Flavonol synthase 1 & JK739019 & {$[59]$} \\
\hline 28 & NbMYB1 & MYB-related transcription factor 1 & JK739024 & {$[57]$} \\
\hline
\end{tabular}

*citations are given to indicate the gene function and not silencing of respective gene by VIGS.

Osmotic stress response was studied by imposing constant low water potential under non-transpiring conditions using polyethylene glycol (PEG). Callus growth on the PEG-stressed leaf disks was measured. Leaf disks from NbP5CS1-, NbADR1-, NtMEK1- and NbETR1-silenced plants showed about $10-20 \%$ more reduction in callus growth compared to control plants (Figure 2B). This finding supports previous reports that P5CS1, ADR1, MEK1 and ETR1 genes play a role in osmotic stress tolerance
[45,64-66]. Interestingly, leaf disks from the NbSOS1-, NbWRKY1- and NbWRKY2-silenced plants showed significant tolerance to PEG stress (Figure 2B). Although SOS1, WRKY1 and WRKY2 genes were previously implicated in imparting abiotic or biotic stress tolerance $[35,57,67]$, it is possible that these genes are not playing positive roles under osmotic stress. VIGS has been previously shown to be a potential method for studying the relevance of only a few genes under water deficit stress 


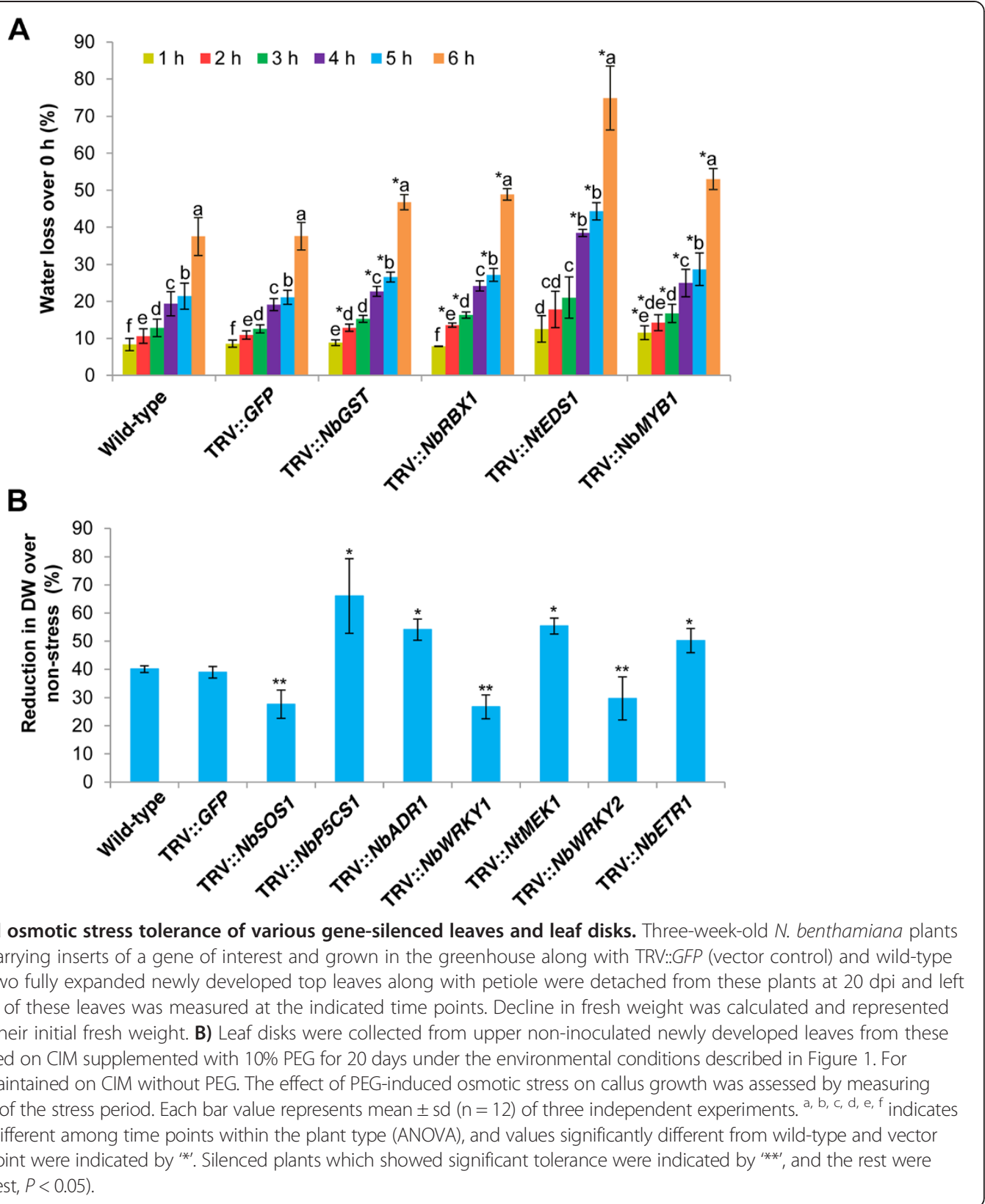

$[21,32]$ because the stress imposition methods used were cumbersome and not feasible for large-scale experiments. However, the results described here show that this lacuna can now be overcome. Taken together, our data suggest that leaf/leaf disks undergoing VIGS can be used to identify and characterize gene functions in dehydration and osmotic stress tolerance in a high-throughput manner.

\section{Salinity stress}

In order to develop a high-throughput protocol for assessing gene function in salinity tolerance, we incubated gene-silenced leaf disks on $\mathrm{CIM}$ with $\mathrm{NaCl}$ followed by callus growth assessment. Leaf disks from NbSOS1silenced plants showed the highest reduction ( 90\%) in growth, both under 100 and $200 \mathrm{mM} \mathrm{NaCl}$ stress, compared to non-stressed plants (Figure 3) while wild-type and vector control plants showed only $\sim 30 \%$ reduction compared to non-stressed plants. Since the Arabidopsis SOS1 gene has been very well shown to impart salinity tolerance [35], this data validates the usefulness of this protocol for salinity tolerance studies. Leaf disks from NbP5CS1-, NbMYC2-, NtRAR1-, NbCTR1- and NtMEK1silenced plants showed about a $60 \%$ reduction in growth over corresponding non-stressed plants. Further, leaf disks 


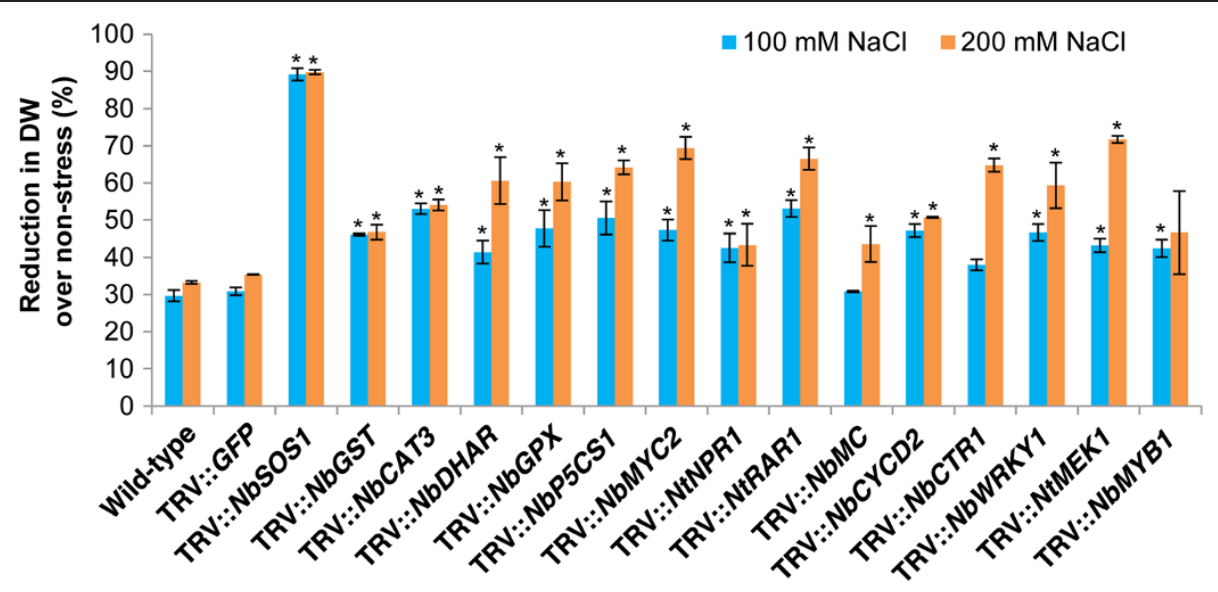

Figure 3 Salinity tolerance of gene-silenced leaf disks. Three-week-old N. benthamiana plants were inoculated with TRV carrying inserts of a gene of interest and grown in the greenhouse along with TRV::GFP (vector control) and wild-type non-inoculated plants. Leaf disks were collected from these plants at $20 \mathrm{dpi}$. Leaf disks were incubated on CIM supplemented with either 100 or $200 \mathrm{mM} \mathrm{NaCl}$ for 20 days under the environmental conditions described in Figure 1. For non-stress, leaf disks were maintained on CIM without NaCl. Callus dry weight was measured at the end of the stress period. Each bar value represents mean $\pm s d(n=12)$ of three independent experiments. Values significantly different from wild-type and vector control plants were indicated by ${ }^{\prime * \prime}$, and the rest were non-significant (Student's $t$-test, $P<0.05$ ).

from NbGST-, NbCAT3-, NbDHAR-, NbGPX-, NtNPR1-, NbMC-, NbCYCD2-, NbWRKY1- and NbMYB1-silenced plants also showed around $40-50 \%$ reduction in growth, suggesting the relevance of these genes in salinity tolerance. Involvement of P5CS1, MYC2, CTR1, MEK1, CAT, DHAR, GPX, NPR1, CYCD2, WRKY1 and MYB1 genes in salinity tolerance has been shown earlier [48,64,68-72]. In addition to these, our results also suggest the plausible role of $M C$ in salt tolerance. Another interesting observation that we made was the higher susceptibility of NtRAR1-silenced plants to salinity, a gene mainly implicated in disease resistance [54], indicating that $R A R 1$ may play a positive role under salinity stress.

\section{High and low temperature stress}

High and low temperature stress tolerances of genesilenced and control plants were assessed by measuring cell membrane stability (CMS) [73]. Under high temperature stress $\left(45^{\circ} \mathrm{C}\right)$, leaf disks obtained from $\mathrm{NbHSP101-}$ silenced plants showed a high reduction (90\%) in CMS while the leaf disks from vector control plants had only $20 \%$ reduction (Figure 4A). This reduction in CMS in silenced plants was highly correlated with reduced transcript levels of HSP101. Semi-quantitative RT-PCR results showed 3.8-fold reduction in HSP101 transcripts in silenced plants when compared to vector control plants (Additional file 1). Several gene-silenced leaf disks also showed significant reduction in their membrane stability. Among them, about $60 \%$ reduction was found in the leaf disks from the NbAPX-, NbMYC2-, NbMC-, NbWRKY1-, NbWRKY2- and NbETR1-silenced plants. This data indicate that NbHSP101 plays an important role in thermotolerance and is consistent with the previous reports [74]. Furthermore, our results show that the genes like MYC2, WRKY2 and ETR1 that are known to play a role in various other abiotic stresses $[48,66,67]$ might also play a role in thermotolerance.

Under low temperature stress $\left(-2^{\circ} \mathrm{C}\right)$, leaf disks from NbAPX-, NbBIP5-, NbP5CS1-, NbPAL1- and NbWRKY1silenced plants showed higher membrane damage compared to control plants (Figure 4B). However, CMS of leaf disks from other gene-silenced plants studied did not significantly differ from the vector control plants. NbAPX-, NbBIP5-, NbP5CS1-, NbPAL1- and NbWRKY1silenced plants showed susceptibility to both high and low temperature stresses, suggesting that these genes may have a general role in protecting the cell membrane during stresses.

\section{Oxidative stress}

Leaf disks from the gene-silenced plants were subjected to oxidative stress by incubating them on menadione-supplemented CIM for callus growth assay. Callus growth of leaf disks from $N b G P X$-silenced plants showed the largest reduction in weight $(\sim 52 \%)$ compared to vector control $(\sim 10 \%)$ (Figure 5). GPX has been previously implicated in regulating ROS during oxidative stress [37]. In addition, leaf disks from plants silenced for other known oxidative stress associated genes like APX, CAT3 and DHAR also showed $30-45 \%$ growth reduction. Our results support previous findings that showed involvement of $A P X$ [75], CAT [76], DHAR [77], SOS1 [78], HSP101 [79], P5CS1 [80], MYC2 [81], PAL1 [82], MEK1 [65] and FLS1 [83] in oxidative stress, thus validating the usefulness of this assay 

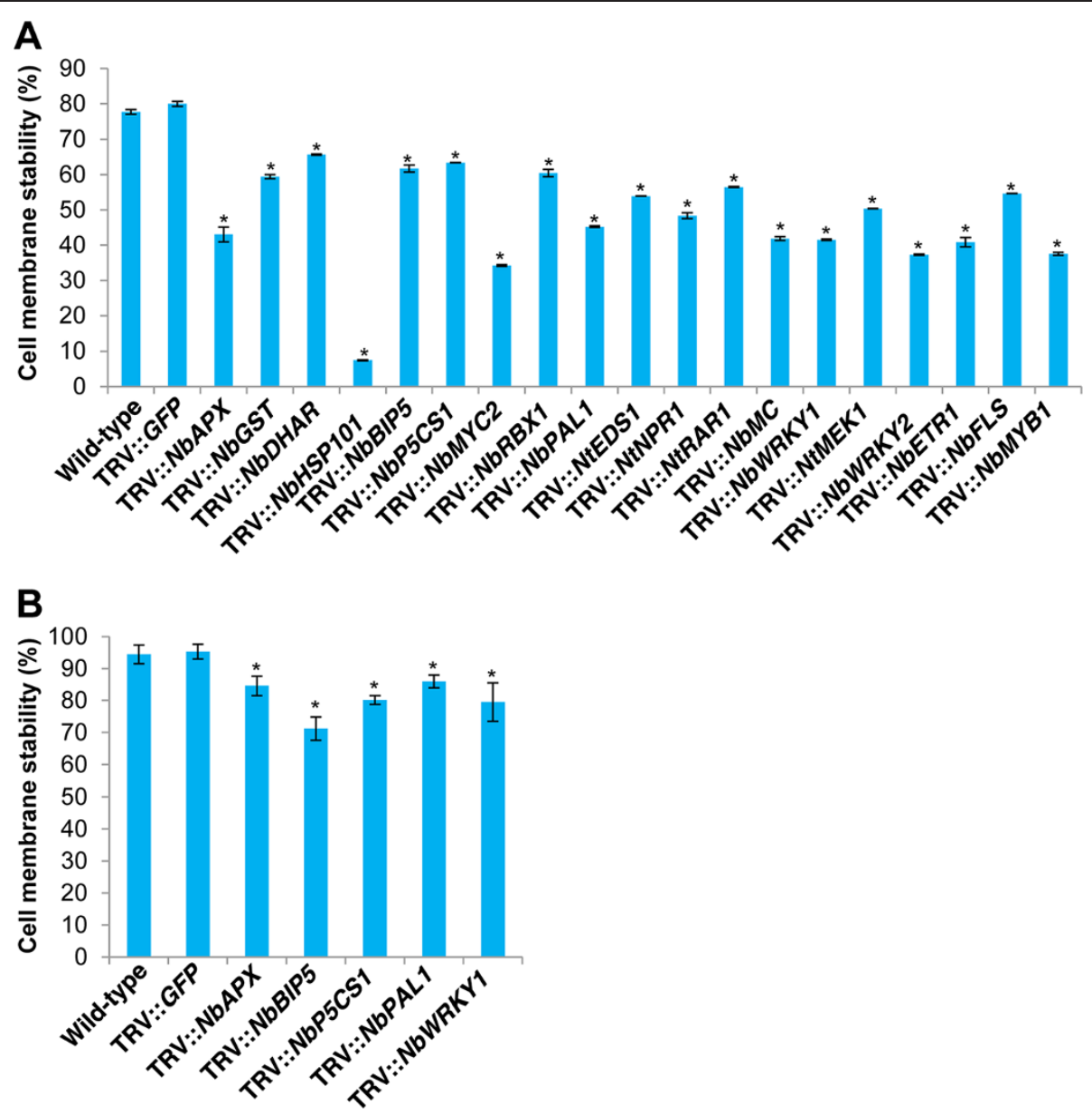

Figure 4 High and low temperatures stress tolerance of leaf disks from gene-silenced plants. Three-week-old N. benthamiana plants were inoculated with TRV carrying inserts of a gene of interest and grown in the greenhouse along with TRV::GFP (vector control) and wild-type non-inoculated plants. Leaf disks were collected from these plants at $20 \mathrm{dpi}$ and floated on deionized water and exposed to either high or low temperature stress. A) For high temperature stress, leaf disks were initially incubated at $35^{\circ} \mathrm{C}$ for $6 \mathrm{~h}$ and then at $45^{\circ} \mathrm{C}$ for $1 \mathrm{~h}$. Another set of disks was maintained under non-stress conditions. Electrical conductivity of the medium was measured at the end of the stress period. B) For low temperature stress, leaf disks were initially incubated at $4^{\circ} \mathrm{C}$ for $12 \mathrm{~h}$ and then at $-2^{\circ} \mathrm{C}$ for $1 \mathrm{~h}$. Another set of samples was maintained under non-stress conditions. Electrical conductivity of the medium was measured at the end of the stress period. Based on electrical conductivity values, cell membrane stability was calculated. Each bar value represents mean $\pm s d(n=12)$ of three independent experiments. Values significantly different from wild-type and vector control plants were indicated by '*', and the rest were non-significant (Student's $t$-test, $P<0.05$ ).

in studying genes associated with oxidative stress. Furthermore, among other assayed plants which showed significant reduction in growth, for the first time we suggest the involvement of $R B X 1$ and CTR1 in oxidative stress. Taken together, we demonstrated that VIGS in combination with callus growth assay is useful for characterizing genes imparting oxidative stress tolerance.

\section{Assessing the response of gene-silenced plants to host and nonhost bacterial pathogen infection}

Abiotic stress tolerance pathways adapted by plants are known to share a significant overlap with pathways involved in plant-pathogen interactions [84]. Hence, apart from abiotic stress tolerance, we also studied responses of the 28 gene-silenced plants to pathogen infection. Two leaves of each gene-silenced plant were spot-inoculated with either a host pathogen, Pseudomonas syringae pv. tabaci, or nonhost pathogens P. syringae pv. tomato $\mathrm{T} 1$ and Xanthomonas campestris pv. vesicatoria expressing GFPuv $[85,86]$. Growth of these bacterial pathogens in the inoculated spots was visualized using UV light under dark. Host pathogen-inoculated spots showed green fluorescent signals reflecting the bacterial colonies. Greater variation in host pathogen growth was observed among different gene-silenced plants (Table 2). Nonhostpathogen-inoculated spots in the wild-type and the vector control plant leaves did not produce any green fluorescence signal as the nonhost resistance mechanism was 


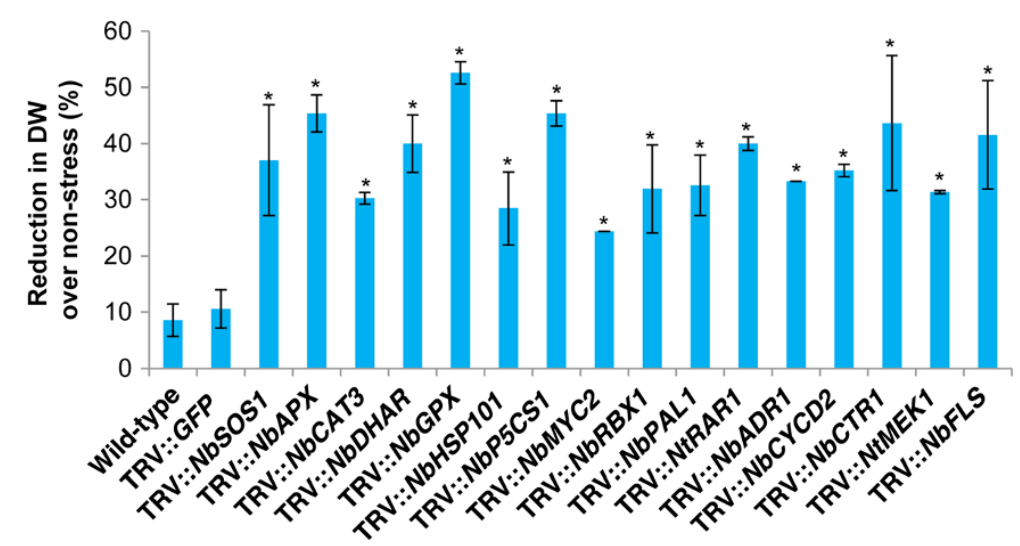

Figure 5 Oxidative stress tolerance of leaf disks collected from gene-silenced plants. Three-week-old N. benthamiana plants were inoculated with TRV carrying inserts of a gene of interest and grown in the greenhouse along with TRV::GFP (vector control) and wild-type non-inoculated plants. Leaf disks were collected from these plants at $20 \mathrm{dpi}$. Leaf disks were incubated on CIM supplemented with or without $10 \mu \mathrm{M}$ menadione for 20 days under the environmental conditions described in Figure 1. Callus dry weight was measured at the end of the stress period, and the percent reduction over corresponding non-stressed samples was calculated. Each bar value represents mean $\pm s d(n=12)$ of three independent experiments. Values significantly different from wild-type and vector control plants were indicated by ${ }^{\prime * \prime}$ and the rest were non-significant (Student's $t$-test, $P<0.05$ ).

fully functional in these plants. In addition to bacterial growth under UV light, visual observations were also made to note disease symptoms (Table 2). Apart from confirming the involvement of several genes such as $E D S 1, R A R 1$ and $A D R 1$ in plant disease resistance as reported before, our results also suggest the plausible role of SOS1 and HSP101, which are mainly associated with abiotic stresses, in biotic stress tolerance.

\section{Identification of genes involved in multi-stress tolerance}

Simulated drought, salinity and oxidative stress responses were tested by incubating leaf disks collected from genesilenced, wild-type and vector control plants on MS medium supplemented with either PEG or $\mathrm{NaCl}$ or menadione, respectively. This assay was performed on MS medium for the convenience of identifying a clear phenotype, which will be difficult on CIM as callus induction and/or growth might interfere with the phenotype. Pathogen response was assessed by inoculating GFPuvexpressing host pathogen P. syringae pv. tabaci and two nonhost pathogens, $P$. syringae $\mathrm{pv}$. tomato $\mathrm{T} 1$ and $X$. campestris pv. vesicatoria, and visualizing the bacterial growth by GFP fluorescence under UV light. Leaf disks from wild-type and vector control plants incubated on abiotic stress medium were healthy and green for about two weeks. However, leaf disks from gene-silenced plants showed various phenotypes including discoloration, spotted cell death and wrinkling. A representative phenotype of leaf disks from NbSOS1-silenced plants is shown in Additional file 2A. Similarly, during pathogen infection, wild-type non-inoculated and vector control plants did show disease symptoms to host pathogen $P$. syringae pv. tabaci, but severe disease symptoms were observed in some of the gene-silenced plants. Some of the genesilenced plants also supported the growth of nonhost pathogens $P$. syringae pv. tomato $\mathrm{T} 1$ and $X$. campestris pv. vesicatoria, while no bacterial growth was observed in wild-type non-inoculated and vector control plants. A representative disease phenotype of $N b G P X$-silenced plants is shown in Additional file 2B. Phenotypic responses were recorded for each gene-silenced leaf disk/plant separately exposed to various different abiotic and biotic stresses (Table 2).

Most of the gene-silenced leaf disks showed susceptibility to salinity and oxidative stress (Table 2), indicating that these two stresses are regulated by a wide range of genes. Interestingly, only a few gene-silenced leaf disks were susceptible to low temperature stress. This may indicate the unique nature of this stress effect and reciprocating plant response. NbGST-, NbWRKY1-, NtMEK1- and NbMYB1-silenced leaf disks showed susceptibility to a wide range of stresses studied. NbP5CS1-silenced leaf disks were susceptible to all abiotic stresses studied. More interestingly, 11 out of 14 genes that were previously implicated to play a role in abiotic stress tolerance- when individually silenced the plants were more susceptible to at least one host or nonhost pathogen infection (Table 2). In addition to identifying new genes not previously implicated in biotic or abiotic stress tolerance, our results also confirmed the previous findings that showed the involvement of some of these genes in both biotic and abiotic stresses. For example, Arabidopsis activation tagged lines constitutively expressing $A D R 1$ exhibited resistance against broad spectrum virulent pathogens through SA-dependent activation of defense genes [55] and also showed tolerance to drought stress through SA-dependent activation of 
Table 2 Responses of gene-silenced leaf disks to abiotic stresses, and bacterial pathogen growth on silenced plants

\begin{tabular}{|c|c|c|c|c|c|c|c|c|}
\hline \multirow{3}{*}{$\begin{array}{l}\text { Name of } \\
\text { silenced gene }\end{array}$} & \multirow{2}{*}{\multicolumn{5}{|c|}{ Abiotic stresses $^{1}$}} & \multicolumn{3}{|c|}{ Disease resistance $^{2}$ (bacterial pathogens) } \\
\hline & & & & & & \multirow{2}{*}{$\begin{array}{l}\text { Host } \\
\text { Pstab }\end{array}$} & \multicolumn{2}{|c|}{ Nonhost } \\
\hline & Salinity & High temperature & Low temperature & Oxidative & Osmoticum & & PstT1 & $\mathrm{XCV}$ \\
\hline$\overline{\mathrm{WT}}$ & * & * & * & * & * & \#\# & No & No \\
\hline TRV::GFP & * & * & * & * & * & \#\# & No & No \\
\hline NbSOS1 & ++++ & * & * & + & * & \#\# & No & $\dagger$ \\
\hline NbAPX & * & ++ & + & +++ & * & \#\# & $\dagger$ & No \\
\hline NbGST & ++ & + & * & ++ & ++ & \#\#\# & $\dagger$ & t \\
\hline NbCAT3 & ++ & * & * & ++ & * & \#\#\# & $\dagger$ & $\dagger$ \\
\hline NbDHAR & + & + & * & ++ & * & \#\# & No & $\dagger$ \\
\hline NbGPX & ++ & * & * & ++++ & * & \#\# & t & No \\
\hline NbFER2 & * & * & * & $*$ & * & \#\# & t & No \\
\hline NbHSP101 & + & ++++ & * & ++ & * & \#\# & No & $\dagger$ \\
\hline NbBIP5 & * & + & ++ & * & * & \#\# & No & No \\
\hline NbP5CS1 & ++ & + & + & +++ & ++++ & \#\#\# & $\dagger$ & No \\
\hline NbCBL1 & * & + & * & + & * & \#\# & No & No \\
\hline NbMYC2 & ++ & ++ & * & + & * & \#\#\# & $\dagger$ & No \\
\hline NbGBP16 & $*$ & * & * & $*$ & * & \#\# & No & No \\
\hline NbRBX1 & * & + & * & + & ++ & \#\# & No & No \\
\hline NbPAL1 & * & ++ & + & ++ & * & \#\# & $\dagger$ & No \\
\hline NtEDS1 & * & ++ & * & * & ++++ & \#\#\# & $\dagger$ & $\dagger$ \\
\hline NtNPR1 & ++ & ++ & * & + & * & \#\#\# & $\dagger$ & No \\
\hline NtRAR1 & ++ & + & * & + & * & \#\#\# & † & t \\
\hline NbADR1 & * & + & * & + & +++ & \#\#\# & t & t \\
\hline NbMC & + & ++ & * & * & $*$ & \#\# & No & No \\
\hline NbCYCD2 & ++ & * & * & ++ & * & \#\#\# & t & t \\
\hline NbCTR1 & + & * & * & ++ & * & \#\# & t & No \\
\hline NbWRKY1 & ++ & ++ & + & * & + & \#\#\# & $\dagger$ & No \\
\hline NtMEK1 & ++ & + & * & ++ & +++ & \#\# & No & No \\
\hline NbWRKY2 & * & ++ & * & * & + & \#\# & No & No \\
\hline NbETR1 & $*$ & ++ & * & + & ++ & \#\# & No & No \\
\hline$N b F L S$ & * & + & * & ++ & * & \#\# & No & $\dagger$ \\
\hline NbMYB1 & ++ & ++ & * & + & ++ & \#\# & No & No \\
\hline
\end{tabular}

${ }^{1}$ Abiotic stress phenotype was represented as ${ }^{*}$ leaf disks with no observable phenotypic changes when compared to wild-type; ${ }^{+}$trivial discoloration; ${ }^{++}$moderate discoloration with wrinkling; ${ }^{+++}$complete discoloration and/or wrinkle with necrotic spots and ${ }^{+++}$complete cell death

${ }^{2}$ The disease symptom development on pathogen-inoculated leaves was scored as percent leaf area covered and represented as \#\# $50 \%$ of the leaf area showing disease symptoms when inoculated with host pathogen Pstab (Pseudomonas syringae pv. tabaci); \#\# $75 \%$ of the leaf area showing disease symptoms when inoculated

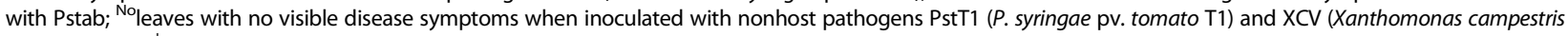
pv. vesicatoria); ${ }^{\dagger}$ up to $50 \%$ of leaf showing disease symptoms when inoculated with PstT1 and XCV.

drought stress-related genes such as DREB2A [66]. The $A D R 1$ mediated drought tolerance in Arabidopsis needed EDS1 [66], a gene that plays a role in disease resistance [63]. These results suggested the role of $A D R 1$ and EDS1 in both biotic and abiotic stresses. Also in our study, both $A D R 1$ - and EDS1-silenced plants showed susceptibility to osmotic stress as well as pathogen infection. GST is also known to be involved in both biotic and abiotic stresses. Silencing of NbGSTU1 in $N$. benthamiana showed significantly higher lesions and more colonization by $\mathrm{Col}$ letotrichum orbiculare [87]. The role GSTs during abiotic stress tolerance mainly through detoxification of ROS has been suggested. Overexpression of GST along with GPX in tobacco enhanced seedling growth under salt stress and also reduced oxidative damage [37]. In our study GST1silenced plants showed susceptibility to salinity, oxidative stress, osmotic stress and pathogen infection thus confirming the role of GST in both biotic and abiotic 
stresses. These findings further suggest the existence of common mechanisms underlying tolerance to abiotic and biotic stresses. Other genes which are commonly required for tolerance to both abiotic and biotic stresses include regulatory genes like transcription factors. For example, the NbWRKY1-silenced leaf disks showed moderate susceptibility to salt, high temperature and PEG-induced osmotic stresses while $N b M Y C 2$-silenced leaf disks were moderately susceptible to salt, high temperature and oxidative stresses. In addition, these silenced plants were also more susceptible to host and nonhost pathogens. The other regulatory gene-silenced leaf disks like $N t R A R 1$, NtNPR1 and NbCTR1 also showed susceptibility to both abiotic and biotic stresses. These results indicate that the high-throughput VIGS methodology used here to study abiotic stress tolerance can also be used to dissect mechanisms involved in multi-stress tolerance of plants.

\section{Validating the function of specific genes at the whole plant level}

In order to validate the results obtained from the leaf disk assays, we chose four genes to confirm their role in stress tolerance at the whole plant level. NbP5CS1, NtEDS1, NbHSP101 and NbSOS1 genes were individually silenced in $N$. benthamiana. Down-regulation of target genes in respective gene-silenced plants was confirmed by semiquantitative RT-PCR (Additional file 1). These genesilenced plants were then individually subjected to various abiotic stresses at the whole plant level, and their responses were recorded as below.

\section{Water deficit stress}

P5CS1 has been shown to impart water deficit stress tolerance in plants by facilitating enhanced biosynthesis and accumulation of proline [45]. Therefore, we selected NbP5CS1-silenced plants for imposing water deficit stress at the whole plant level. Similarly, the AtEDS1 has been implicated in resistance against powdery mildew disease caused by Erysiphe necator [88] and water deficit stress tolerance [64]. Our results also showed that the NtEDS1 gene is important for basal resistance against host pathogen P. syringae pv. tabaci (Table 2). Further, the leaf disk assay and detached leaf assay showed that NtEDS1silenced plants were highly susceptible to osmotic stress (Table 2) and dehydration stress (Figure 2), respectively. Therefore, we also studied the response of NtEDS1silenced plants under water deficit stress at the whole plant level.

Photosynthetic performance of NbP5CS1- and NtEDS1silenced plants maintained under water deficit stress of $50 \%$ FC was measured. NbP5CS1- and NtEDS1-silenced plants independently showed more than $80 \%$ reduction in photosynthetic efficiency over non-stressed plants compared to only a $50 \%$ reduction in control plants
(Figure 6A). These data suggest that the photosynthetic machinery is greatly impaired in these gene-silenced plants upon drought stress. Less reduction in photosynthetic efficiency under stress is one of the mechanisms adapted by stress tolerant plants to cope with the water deficit stress [89]. Hence, greater reduction in the photosynthetic efficiency in the NbP5CS1- and NtEDS1-silenced plants reflects the relevance of these two genes in water deficit stress tolerance. Taken together, these results validate the VIGS methodology developed for studying water deficit or dehydration or osmotic stress tolerance.

\section{Salinity stress}

We selected the NbSOS1 gene in order to validate our salinity screening assays. NbSOS1-silenced whole plants were irrigated with saltwater by gradually increasing salt concentration from 100 to $300 \mathrm{mM}$ at 5-day intervals. Salinity stress response was assessed at the end of the stress period by measuring photosynthesis. NbSOS1 silenced plants under salt stress showed reduced growth compared to corresponding control plants, and no growth differences were observed under non-stress conditions (Figure 6B). Consistent with our observations, the growth of the sos 1 Arabidopsis mutant was inhibited by high $\mathrm{Na}+[35]$. In addition to growth reduction, raised pustules (salt accumulated pockets) were observed on the adaxial surface of NbSOS1-silenced $N$. benthamiana leaves (Figure 6C). Since salt tolerance of plants depends on the ability to exclude $\mathrm{Na}$ + from the shoot and maintain a low cellular $\mathrm{Na}+/ \mathrm{K}+$ ratio [90], one of the reasons for the susceptibility of silenced plants to salt might be the disruption of $\mathrm{Na}+$ homeostasis in the cell. Salt has been previously shown to inhibit photosynthesis [91], and SlSOS1 overexpression in tomato prevented $\mathrm{Na}+$ from reaching the photosynthetic tissues by extruding $\mathrm{Na}+$ out of the root and also retaining $\mathrm{Na}+$ in the stems [92]. Consistent with this, NbSOS1-silenced $N$. benthamiana plants exposed to salt stress in this study showed about $10 \%$ reduction in photosynthetic efficiency (Figure 6D).

\section{High temperature stress}

NbHSP101-silenced whole plants exposed to high temperature stress showed less membrane stability compared to corresponding vector control plants (Figure 6E). Consistently, Arabidopsis hot mutants with reduced thermotolerance, expressing lower levels of AtHSP101, had higher membrane damage under high temperature stress [93]. HSP101 is an important chaperon protein known to be involved in imparting thermotolerance in plants [94,95]. Overexpression of AtHSP101 has been shown to improve thermotolerance in rice [74]. Since high temperature stress predominantly affects the membrane characteristics, membrane stability assay is commonly used to assess the stress response of plants $[93,96]$. Susceptibility of NbHSP101- 

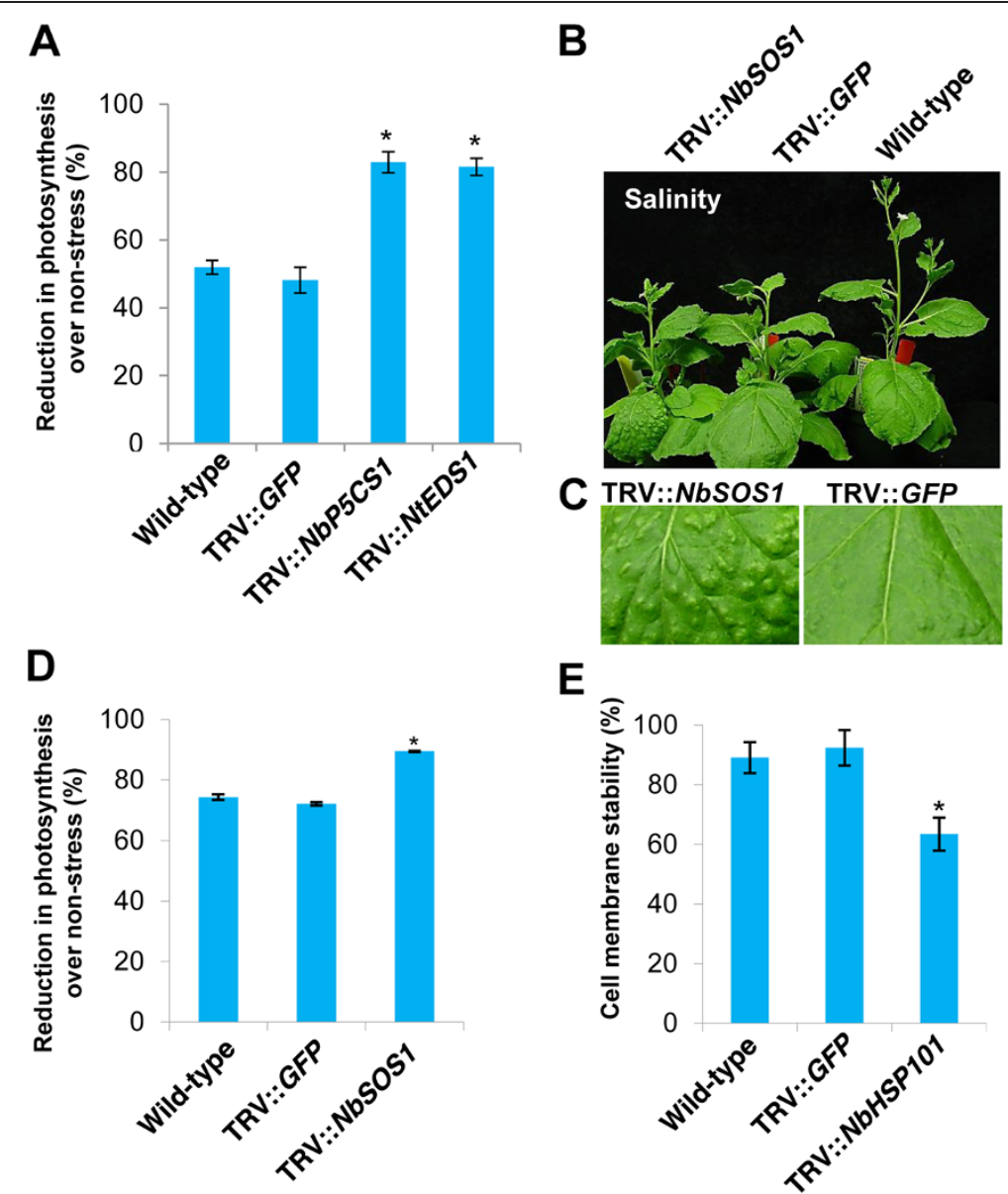

E

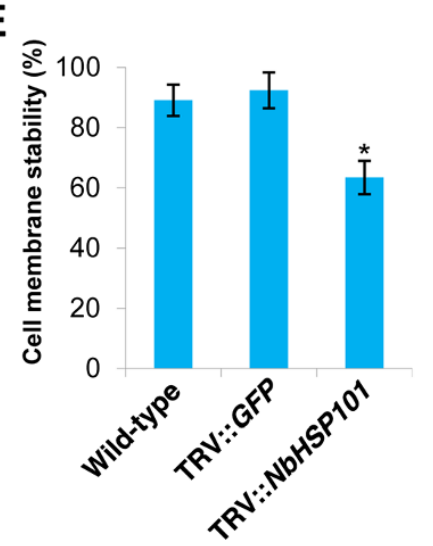

Figure 6 Abiotic stress response of selected genes at the whole plant level. Three-week-old N. benthamiana plants were inoculated with respective TRV derivatives, TRV::GFP and maintained in the greenhouse along with wild-type non-inoculated plants. A) Photosynthetic rates of NbP5CS1- and NtEDS1-silenced plants under water deficit stress. Stress was imposed on plants at 20 days after silencing by gradually bringing down the water level to 50\% FC over a period of 15 days. Another batch of plants was maintained under non-stress conditions. Photosynthetic rates were measured in the third newly formed and fully expanded leaf. B) Effect of salt stress on NbSOS1-silenced plants. NbSOS1-silenced plants were irrigated with $\mathrm{NaCl}$ solution at 20 dpi while gradually exposing plants to higher $\mathrm{NaCl}$ concentration from $100 \mathrm{mM}$ for 5 days, then $200 \mathrm{mM}$ for 5 days and subsequently to $300 \mathrm{mM}$ for 5 days. Another batch of plants was maintained under non-stress conditions. Photographs were taken at the end of the stress period. C) Leaf from NbSOS1-silenced plant showing salt pustules in the adaxial surface due to higher salt accumulation. D) Photosynthetic rates were measured at the end of the stress period. E) Effect of heat stress on cell membrane stability of NbHSP101-silenced plants. Wild-type, vector control and NbHSP101-silenced whole plants were initially acclimated with mild temperatures $\left(35^{\circ} \mathrm{C}\right.$ for $\left.6 \mathrm{~h}\right)$ and subsequently exposed to high temperature stress $\left(45^{\circ} \mathrm{C}\right.$ for $\left.1 \mathrm{~h}\right)$. Another batch of plants was maintained under non-stress conditions. Leaf disks were collected from these plants at the end of stress, and ion leakage was measured as described in the Materials and Methods section. Each bar value represents mean $\pm s d(n=5)$ of three independent experiments. ${ }^{\prime * \prime}$ suggests values were significantly different from wild-type and vector control plants (Student's $t$-test, $P<0.05)$.

silenced plants to high temperature validates the results from leaf disk experiments that showed a similar trend (Figure 6E).

\section{Conclusions}

During functional characterization and genetic manipulation studies of plants for stress tolerance, apart from testing a candidate gene under particular stress, it is important to screen them for broad spectrum stress tolerance $[84,97]$. These screens will not only help to identify the appropriate genes that impart tolerance to multiple stresses, but will also allow researchers to test susceptibility, if any, to other stresses [98]. These notions mandate quick and authoritative forward and reverse genetics assays for testing the relevance of a particular gene under multiple stresses. Despite its potential, a VIGS-based transient gene silencing system has not been used before for large-scale screening either to identify genes involved in abiotic stress tolerance or to dissect multi-stress tolerance. As depicted in Figure 7, we propose a methodology, utilizing VIGS in leaf disks combined with simple stress effect quantification methodologies, that will pave the way for 


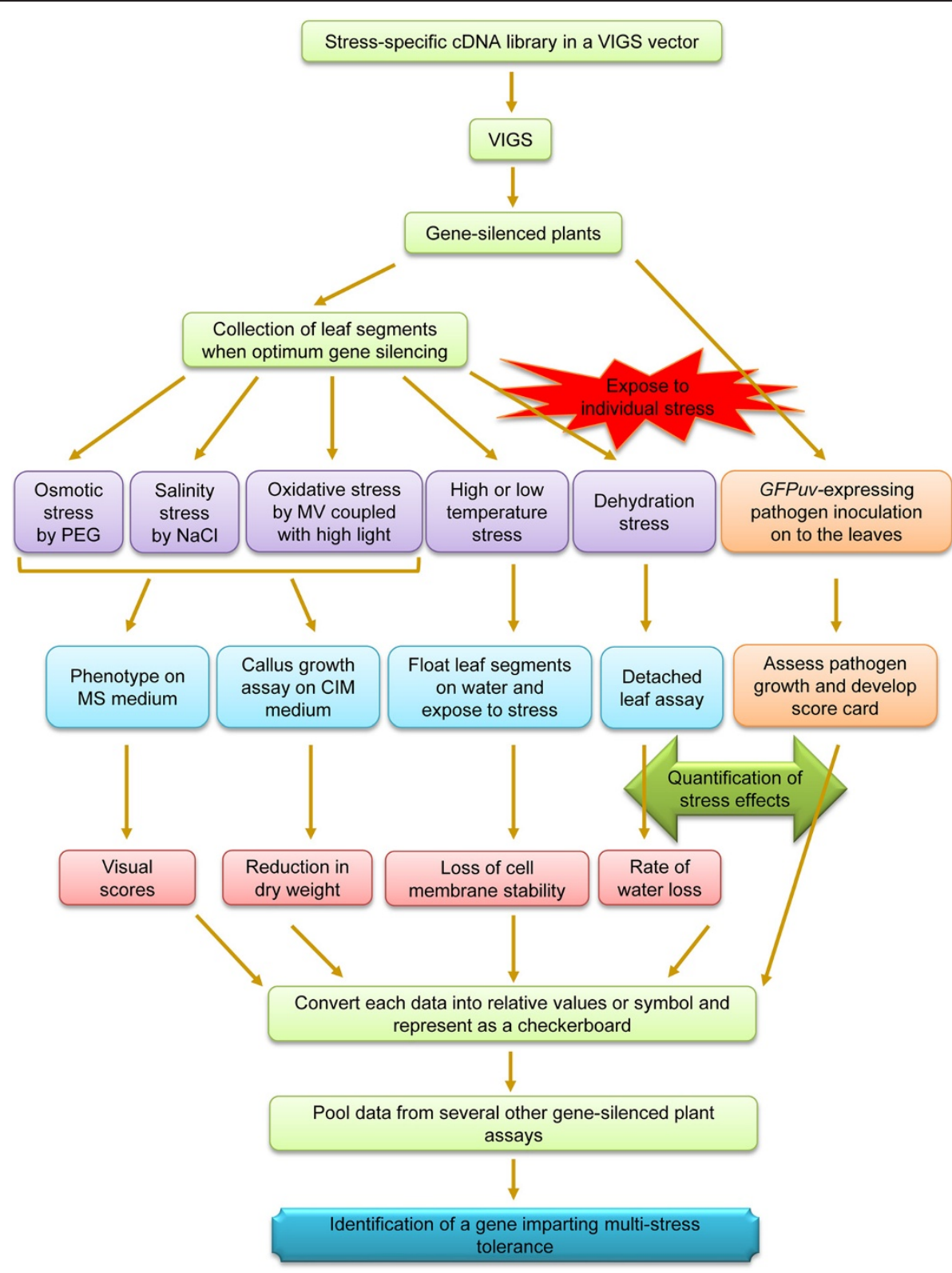

Figure 7 Proposed VIGS-based high-throughput screen to identify genes involved in multi-stress tolerance in $N$. benthamiana. A cDNA library from the plants treated with various abiotic stresses can be cloned into pTRV2 vector. This library can be used for a forward genetic screening. TRV-VIGS can be used to silence each of these genes, and the silenced plants can be evaluated for their multi-stress tolerance by using the high-throughput methods described and demonstrated in this manuscript. Leaf disks can be collected from a silenced plant and exposed to specific abiotic stress. Such stress-treated leaf disks can be analysed for stress effects by using various physiological and biochemical assays. Similarly, the silenced plants can be inoculated with pathogens expressing GFPuv and their growth can be visualized by the naked eye under UV light in the dark. Based on this assay, genes involved in basal and nonhost disease resistance can be identified. Finally, relative scores can be assigned in a checkerboard for each of the stress treatments and compared with control plants. This procedure can be followed for a large number of silenced plants and thereby multi-stress tolerant plants can be identified.

such screening in the future. This methodology will facilitate identification of a single gene that can impart multistress tolerance or tolerance to specific stress with no negative effect on other stresses. Using this methodology, as a proof of concept, we screened 28 genes and identified genes that are important for imparting tolerance to various abiotic stresses and disease resistance. A few interesting findings from this screen which have not been shown before are the involvement of $N b R B X 1$ and $N b C T R 1$ in oxidative stress; NtRAR1 and NtNPR1 in salinity stress; and NbSOS1 and NbHSP101 in biotic stress. In addition to identifying genes involved in multi-stress 
tolerance, for the first time we demonstrate that VIGS can be effectively used to assess the relevance of genes involved in thermotolerance. The methodology described in this manuscript will be useful for large-scale testing of genes involved in thermotolerance pathways. Our results suggest the involvement of NtEDS1, NbETR1, NbWRKY2 and $N b M Y C 2$ in thermotolerance.

The VIGS-mediated high throughput methodology that we have described in this manuscript has several advantages to analyze the functional role of putative stressinduced genes. First, it allows precise stress imposition and quantification of stress effects using less sophisticated laboratory facilities with minimal growth chamber space and time. Second, genes can be characterized in a highthroughput manner for multi-stress tolerance using a single plant as this methodology requires less plant material. Third, experiments can be repeated multiple times since the duration of the whole experiment is shorter than whole plant assays. The limitation of this methodology is that it will only suggest the possible role of a gene under a particular stress and necessitates the study at whole plant level for further confirmation.

\section{Methods}

\section{Plant growth and environmental conditions}

Nicotiana benthamiana seeds were germinated in flats containing soilless potting mixture, Metro-Mix 830 (SUNGRO Horticulture Distribution, Inc., Bellevue, WA, USA).Three-week-old individual seedlings were transplanted into pots (10 cm diameter) containing BM7 (BFG Supply, Minneapolis, MN, USA). Fertilizer (20-10-20) solution, along with soluble trace element mix (The Scotts Co., Marysville, OH, USA), was applied as needed. Plants were grown in the greenhouse under day/night temperature of $19 \pm 2^{\circ} \mathrm{C} / 18 \pm 2^{\circ} \mathrm{C}$ and photoperiod $\left(600 \mu \mathrm{mol} \mathrm{m} \mathrm{m}^{-2} \mathrm{~s}^{-1}\right.$ light intensity) of $14 \mathrm{~h} / 10 \mathrm{~h}$, and relative humidity of 65\%-70\%.

\section{VIGS constructs}

Total RNA was extracted from $N$. benthamiana or $N$. tabacum leaf tissues, and first-strand cDNA was synthesized using oligo- $(\mathrm{dT})_{15}$ primers. Using respective gene-specific primers (Additional file 3), specific fragments (300-580 bp range) were PCR amplified and cloned into Gateway ready $p T R V 2$ vector [19] by following the manufacturer's instructions (Invitrogen Corporation, Carlsbad, CA, USA). The resulting constructs were named according to the putative function of the stress gene (Table 1). TRV::NbPDS, TRV::NbChlH and TRV::GFP (NbPDS, N. benthamiana phytoene desaturase; NbChlH, $N$. benthamiana Mg-chelatase H subunit; and GFP, green fluorescent protein, whose sequence does not have any homology with the plant DNA and therefore will not cause any silencing) constructs were used as gene silencing markers and vector control [34]. Inserts within the $p T R V 2$ vector derivatives were confirmed by sequencing. Plasmids were mobilized into Agrobacterium tumefaciens strain GV2260 by electroporation. VIGS vectors were obtained from Dr. S.P. Dinesh-Kumar (University of CaliforniaDavis, USA; Additional file 4). All gene fragments used in this study were designed using siRNA scan software [99] to minimize possible off-target silencing.

\section{VIGS protocol}

Agrobacterium carrying $p T R V 1$ or $p T R V 2$ derivatives were grown at $28^{\circ} \mathrm{C}$ in $\mathrm{LB}$ medium containing appropriate antibiotics. Cells were harvested from overnight grown cultures, resuspended in the inoculation buffer (10 mM MES, $\mathrm{pH}$ 5.5; $200 \mu \mathrm{M}$ acetosyringone), and incubated for $2 \mathrm{~h}$ at room temperature in a shaker. Agrobacterium strains $\left(\mathrm{OD}_{600}=0.5\right)$ containing $p T R V 1$ and one of the $p T R V 2$ derivatives were mixed at $1: 1$ ratio in $5 \mathrm{mM}$ MES buffer (pH 5.5) and inoculated into $N$. benthamiana leaves, using a needleless syringe [19]. The inoculated plants were maintained in the greenhouse at $19 \pm 2^{\circ} \mathrm{C}$ for effective viral infection and spread.

\section{Assessing the progression and persistence of gene silencing in excised leaf disks}

Progression of gene silencing: Leaf disks (11 mm diameter) were collected from respective gene-silenced, vector control (TRV::GFP) and non-inoculated wild-type plants at 8 days post-inoculation (dpi) and incubated on MS medium [4.32 g of MS minimal salts (GIBCO BRL Rockville, Maryland, U.S.A), $1 \mathrm{ml}$ vitamin stock solution $\left(0.5 \mathrm{mg} \mathrm{ml}^{-1}\right.$ nicotinic acid, $0.5 \mathrm{mg} \mathrm{ml}^{-1}$ pyridoxine, $0.5 \mathrm{mg} \mathrm{ml}^{-1}$ thiamine- $\mathrm{HCl}), 30 \mathrm{~g}$ sucrose, $1 \mathrm{~g}$ phytagel per liter of medium, $\mathrm{pH}$ 5.7] for a week and changes in the phenotype were recorded at two-day intervals.

Persistence of gene silencing: Leaf disks were collected from respective gene-silenced, vector control and noninoculated wild-type plants at $20 \mathrm{dpi}$ and incubated on MS medium or callus induction medium [CIM, MS minimal salts $4.32 \mathrm{~g}$, vitamin stock $1 \mathrm{ml}$, myo-inositol $100 \mathrm{mg}$, glucose $20 \mathrm{~g}$, 2, 4-D $0.5 \mathrm{mg}$, kinetin $0.3 \mathrm{mg}$, IAA $5 \mathrm{mg}$, phytagel $1 \mathrm{~g}$ per litre of medium, $\mathrm{pH}$ 5.7]. In order to prevent bacterial contamination, cefotaxime $200 \mu \mathrm{g} \mathrm{ml}^{-1}$ and ticarcillin $100 \mu \mathrm{g} \mathrm{ml}^{-1}$ were added to the medium. Persistence of the expected phenotypes was monitored for an additional 20 days. Another set of leaf disks incubated on the same CIM was harvested after 20 days culturing and used for RNA isolation to analyze respective endogenous transcript levels of silenced genes. Semi-quantitative RT-PCR was performed using specific primers (Additional file 3).

\section{Stress treatment for excised leaf disks}

Leaf disks (11 mm diameter) were excised from respective gene-silenced, vector control and non-inoculated wild- 
type plants grown under non-stress conditions at $20 \mathrm{dpi}$ and exposed to various abiotic stresses as described below.

Osmotic stress: Leaf disks were incubated on MS medium supplemented with 10\% PEG-10000 (Sigma Aldrich Inc., St. Louis, MO, USA), and the phenotypic changes were observed at 15 days after incubation. To assess PEG-induced osmotic stress effects on callus growth in silenced plants, leaf disks were incubated on CIM supplemented with 10\% PEG-10000. Increase in growth of leaf disks was assessed by measuring dry weight at 20 days after incubation. PEG plates were prepared according to a previously published protocol [60]. Osmotic stress protocols that we used were slightly modified from protocols described previously $[100,101]$.

Salinity stress: Leaf disks were incubated on MS medium supplemented with $200 \mathrm{mM} \mathrm{NaCl}$, and the phenotypic changes were observed at 15 days after incubation. To measure the effect of salt stress on callus growth, leaf disks were incubated on CIM supplemented with either $100 \mathrm{mM}$ or $200 \mathrm{mM} \mathrm{NaCl}$. Increase in growth of leaf disks was measured at 20 days after incubation. Stress protocol that we used for callus growth assay was similar to the previously established protocol [100,102].

High temperature stress: Leaf disks were floated on deionized water and exposed to an acclimation temperature of $35^{\circ} \mathrm{C}$ for $6 \mathrm{~h}$ and then to the severe temperature of $45^{\circ} \mathrm{C}$ for $1 \mathrm{~h}$. Cell membrane stability (CMS) was assessed at the end of the stress period as described previously [60].

Low temperature stress: Leaf disks were floated on deionized water and exposed to an acclimation temperature of $4^{\circ} \mathrm{C}$ for $12 \mathrm{~h}$ and then to the severe low temperature of $-2^{\circ} \mathrm{C}$ for $1 \mathrm{~h}$. CMS was assessed at the end of the stress as described previously [60].

Oxidative stress: Leaf disks were incubated on MS medium supplemented with $10 \mu \mathrm{M}$ menadione sodium bisulfite (Sigma Aldrich Inc., St. Louis, MO, USA), and phenotypic changes were observed at 15 days after incubation. To study the influence of oxidative stress on callus growth, leaf disks were incubated on CIM supplemented with $10 \mu \mathrm{M}$ menadione sodium bisulfite for 20 days. Reduction in callus dry weight was measured at the end of the stress period.

\section{Quantification of rate of water loss by detached leaf assay}

This assay was performed for assessing the dehydration avoidance of gene-silenced plants by measuring the rate of water loss in detached leaves. Leaves were detached from respective gene-silenced, vector control and non-inoculated wild-type plants, and air dried on the bench under controlled environmental conditions (temperature $20^{\circ} \mathrm{C}$, light $100 \mu \mathrm{mol} \mathrm{m} \mathrm{m}^{-2} \mathrm{~s}^{-1}$ and relative humidity 30-35\%). Reduction in fresh weight over time was measured at $1 \mathrm{~h}$ intervals over a $6 \mathrm{~h}$ period, and water loss rate was calculated using the formula given below. This assay was modified from a previously published protocol [60].

Rate of water loss $(\%)=($ Fresh weight at time 'zero'/ Fresh weight at time 'n') x 100

\section{Whole plant stress treatment}

A new batch of respective gene-silenced, vector control and non-inoculated wild-type plants were grown in the greenhouse under non-stress conditions and subjected to the following stresses.

Water deficit stress: Plants were exposed to gradual water deficit stress by maintaining them at $80 \%$ field capacity (FC) for 5 days, followed by $60 \%$ FC for 5 days and $50 \%$ FC for 5 days [103]. The amount of water lost through evapotranspiration was replenished by weighing the pots daily at a fixed time of the day. Stress responses were quantified at the end of the stress period by assessing reduction in photosynthetic rate. This method is a modification from a previously published protocol [32].

Salinity stress: Plants were exposed to gradual salt stress by irrigating them with $100 \mathrm{mM} \mathrm{NaCl}$ solution for 5 days followed by $200 \mathrm{mM}$ solution for 5 days and then $300 \mathrm{mM}$ solution for 5 days. Salinity stress responses were quantified at the end of the stress period by measuring the reduction in photosynthetic rates.

High temperature stress: To assess thermotolerance, plants were exposed to high temperature stress under controlled environmental conditions in a growth chamber. Plants were initially acclimated by exposing them to $35^{\circ} \mathrm{C}$ for $6 \mathrm{~h}$ and then to the challenging temperature of $45^{\circ} \mathrm{C}$ for $1 \mathrm{~h}$; stress responses were quantified by measuring CMS [96].

\section{Pathogen assays}

Pseudomonas syringae strains were grown in King's B medium; Xanthomonas campestris pv. vesicatoria was grown in LB medium at $30^{\circ} \mathrm{C}$. Bacterial cells were collected by centrifugation of overnight grown culture at 2,700 $\mathrm{g}$ for $10 \mathrm{~min}$, washed twice in sterile water, and resuspended in sterile water to the desired concentrations. The bacterial suspensions were spot-inoculated at a concentration of $1 \times 10^{5}$ colony forming units (CFU) onto the fully expanded third leaf from the top of the respective gene-silenced $N$. benthamiana plants, three weeks after TRV inoculation, using a needleless syringe as described previously [87]. Growth of host pathogen P. syringae pv. tabaci and nonhost pathogens $P$. syringae $\mathrm{pv}$. tomato $\mathrm{T} 1$ and $X$. campestris pv. vesicatoria was observed in gene-silenced plant leaves using respective GFPuv-expressing bacteria [85], in addition to visual observations on disease symptom development.

\section{Semi-quantitative RT-PCR}

Confirmation for presence of virus: RT-PCR was performed to determine the presence of TRV in the inoculated 
plants. Total RNA was isolated from newly developed upper non-inoculated leaves, and virus-specific cDNA was synthesized using $T R V$-coat protein specific reverse primer (Additional file 3).

Confirmation of endogenous gene transcript levels by $R T-P C R$ : To quantify the respective endogenous transcript levels in silenced plants, RT-PCR was performed using specific primers given in the Additional file 3. Total RNA was isolated from newly developed upper non-inoculated leaves, and RNA samples were treated with RNAse-free DNAse prior to reverse transcription reaction using the RT-PCR Kit (TURBO ${ }^{\text {me }}$ DNase, Invitrogen, Grand island, NY, USA). First-strand cDNA was synthesized by reverse transcribing $2 \mu \mathrm{g}$ of total RNA (Omniscript RT kit; Qiagen Inc, Valencia, CA, USA) using oligo- $\mathrm{dT}_{(15)}$ primers, and RT-PCR was performed. To study the down-regulation of transcripts, PCR primers that anneal outside the region targeted for silencing were used to ensure that only endogenous genes would be tested. The elongation factor- 1 alpha of $N$. benthamiana (NbEF1 $\alpha)$ was used as an internal control.

\section{Estimation of cell membrane stability}

Leaf disks (11 $\mathrm{mm}$ in diameter) were rinsed in deionized water to remove the solutes leaked at the cut ends and then incubated in deionized water for $8 \mathrm{~h}$ at $25^{\circ} \mathrm{C}$ under constant shaking $(25 \mathrm{rpm})$. The conductivity of electrolytes that leaked into water from stressed leaf samples was recorded (T1) using conductivity bridge (Orion pHuture MMS555A; Thermo Electron Corporation, Beverly, MA, USA). Subsequently, leaf disks were boiled for $30 \mathrm{~min}$, and a final reading was recorded (T2) after cooling to room temperature. Similarly, conductivity was also measured using non-stressed samples ( $\mathrm{C} 1$ and $\mathrm{C} 2)$. The membrane stability was calculated using the below formula [73].

$$
\text { Cell membrane stability }(C M S)=\frac{\left[1-\left(\frac{T 1}{T 2}\right)\right]}{\left[1-\left(\frac{C 1}{C 2}\right)\right]} \times 100
$$

\section{Measurement of photosynthetic rate}

Photosynthetic rates $\left(\mu \mathrm{mol} \mathrm{m} \mathrm{m}^{-2}\right)$ were measured on the third leaf down from the top using a portable photosynthesis system (LI-6400; LI-COR, Lincoln, NE, USA) at an ambient $\mathrm{CO}_{2}$ concentration $\left(370 \mu \mathrm{mol} \mathrm{mol}{ }^{-1}\right)$ and $1,000 \mu \mathrm{mol} \mathrm{m} \mathrm{m}^{-2} \mathrm{~s}^{-1}$ light intensity using LICOR light source at a chamber temperature of $28^{\circ} \mathrm{C}$. The values were expressed as percent reduction over non-stressed plants.

\section{Statistical analysis}

The data points were analyzed for significant differences in stress effects on each gene-silenced plants when compared to wild-type and vector control (TRV::GFP) plants $(P<0.05)$ by Student's $t$-test. One-way ANOVA (generalized linear model procedure; SAS software, SAS Institute Inc., Cary, NC, USA) analysis was performed to test the significant difference in water loss between time points within each gene-silenced plant. The statistical significance of values in graphs was indicated either as asterisks ( $t$-test) or as letters (ANOVA). Unless otherwise specified, values not significantly different from wild-type and vector control plants were not shown in figures.

\section{Additional files}

\begin{abstract}
Additional file 1: RT-PCR showing reduction in endogenous transcript levels of four selected stress-responsive genes in silenced plants. Total RNA was extracted from wild-type-, TRV::GFP- (vector control), TRV::NbSOS1-, TRV::NbP5CS1-, TRV::NbHSP101- and TRV::NtEDS1-inoculated plant leaves at 0 and 20 dpi. A) Semi-quantitative RT-PCR was performed using first-strand CDNA as a template with 30 PCR cycles using respective gene-specific primers, and the PCR product was resolved on agarose gel. dpi, days post-infiltration; GOI, gene of interest; EFla, Elongation factor 1 alpha as loading control. B) The band intensity of RT-PCR products was analyzed using ImageJ software version 1.34 s (National Institutes of Health) to calculate the reduction in transcript levels in silenced plants keeping the expression levels of wild-type plants as one.
\end{abstract}

Additional file 2: Representative phenotypes used in abiotic stress and pathogen susceptibility scoring. A) Phenotype of TRV::NbSOS1-silenced leaf disks. Leaf disks were incubated on MS medium supplemented with $200 \mathrm{mM} \mathrm{NaCl}$, and the photograph was taken 15 days after incubation on stress medium. B) Response of gene-silenced plants to Pseudomonas syringae pv. tomato T1 inoculation. TRV::NbGPX, vector control and wild-type $N$. benthamiana leaves were inoculated with a nonhost pathogen, $P$. syringae pv. tomato T1, at a concentration of approximately $1 \times 10^{5} \mathrm{cfu} \mathrm{ml}^{-1}$ by using a needleless syringe. Leaves were photographed at $5 \mathrm{dpi}$.

Additional file 3: Primers used in the study.

Additional file 4: TRV-based VIGS constructs. Tobacco rattle virus (TRV) CDNA clones are placed in between the duplicated CaMV35S promoter (2X35S) and nopaline synthase terminator (NOSt) in a T-DNA vector. LB and $\mathrm{RB}$, left and right borders of T-DNA; RdRp, RNA-dependent RNA polymerase; $M P$, movement protein; $16 \mathrm{~K}, 16 \mathrm{kDa}$ cysteine rich protein; $\mathrm{CP}$, coat protein; and Rz, self-cleaving ribozyme. A) TRV RNA1-based viral vector, plasmid of $6.791 \mathrm{~kb}$ [NCBI\# AF406990], is referred to as pTRV1. B) TRV RNA2-based viral vector, plasmid of $9.663 \mathrm{~kb}$ [NCBI\# AF406991], is referred to as pTRV2. It's a modified vector compatible for Gateway recombination. The gene fragments were cloned into pTRV2 by replacing the $c c d B$ gene, and these derived constructs were used for silencing studies. Details of this vector were described previously [31].

\section{Abbreviations}

ADR1: Activated disease resistance 1; APX3: Ascorbate peroxidase 3; BIP5: Binding protein 5; CAT3: Catalase isozyme 3; CBL1: Calcineurin B-like protein 1; ChlH: Mg-chelatase H subunit; CIM: Callus induction medium; CMS: Cell membrane stability; CTR1: Constitutive triple response 1-like protein kinase; CYCD2: Cyclin D2.1 protein; DHAR1: Dehydroascorbate reductase 1; dpi: Days post-inoculation; EDS1: Enhanced disease susceptibility 1; EF1a: Elongation factor-1 alpha; EST: Expressed sequence tag; ETR1: Ethylene response 1; FC: Field capacity; FER2: Ferritin 2; FLS1: Flavonol synthase 1; GBP16: Putative monomeric G-protein 16; GFP: Green fluorescent protein; GPX2: Glutathione peroxidase 2; GST1: Glutathione S-transferase 1; HSP101: 101 kDa Heat shock protein; MC: Metacaspase type Il; MEK1: MAP kinase/ERK kinase 1; MYB1: MYB-related transcription factor 1; MYC2: MYC-related transcription factor 2; Nb: Nicotiana benthamiana; NPR1: Non-expresser of pathogenesis related gene 1; Nt: Nicotiana tabacum; P5CS1: Delta-1-pyrroline-5-carboxylate synthetase 1; PAL1: Phenylalanine ammonia-lyase 1; PDS: Phytoene desaturase; PEG: Polyethylene glycol; Pstab: Pseudomonas syringae pv. tabaci; PstT1: Pseudomonas syringae pv. tomato T1; PTGS: Post-transcriptional gene silencing; RAR1: Required for Mla12 resistance 1; RBX1: Ring box 1 like protein; SOS1: Salt overly sensitive 1; TRV: Tobacco rattle virus; 
VIGS: Virus-induced gene silencing; WRKY1: WRKY DNA-binding protein 1; WRKY2: WRKY DNA-binding protein 2; XCV: Xanthomonas campestris pv. vesicatoria.

\section{Competing interests}

The authors declare that they have no competing interests.

\section{Authors' contributions}

RV performed all abiotic stress experiments, analyzed the data, prepared figures and drafted background and methods sections. MS and KSM designed the study and coordinated the experiments. MS performed pathogen assay/data analysis. RV, MS and KSM wrote the manuscript. MU edited the draft manuscript. All authors read and approved the final manuscript.

\section{Acknowledgments}

This work was supported by The Samuel Roberts Noble Foundation. Travel and research support to VR at KSM lab was supported by The Wood Whelan Research Fellowships of International Union of Biochemistry and Molecular Biology (WWF-IUBMB) and The Kirkhouse Trust, Oxford, UK. Authors thank Ms. Janie Gallaway for excellent plant care, Drs. Yun Kang and Xin Shun Ding for critical reading of the manuscript, and Mrs. Jackie Kelley for editorial corrections.

\section{Author details}

${ }^{1}$ Plant Biology Division, The Samuel Roberts Noble Foundation, 2510 Sam Noble Pkwy., Ardmore, OK 73402, USA. ²Department of Crop Physiology, University of Agricultural Sciences, GKVK, Bangalore 560 065Karnataka, India. ${ }^{3}$ Present address: VR: Department of Crop, Soil and Environmental Sciences, University of Arkansas, Fayetteville, AR 72701 USA; MS: National Institute of Plant Genome Research, Aruna Asaf Ali Marg, New Delhi 110 067, India.

Received: 17 July 2013 Accepted: 21 November 2013

Published: 1 December 2013

\section{References}

1. Seki M, Narusaka M, Ishida J, Nanjo T, Fujita M, Oono Y, Kamiya A, Nakajima M, Enju A, Sakurai T, et al: Monitoring the expression profiles of 7000 Arabidopsis genes under drought, cold and high-salinity stresses using a full-length cDNA microarray. Plant J 2002, 31(3):279-292.

2. Kreps JA, Wu Y, Chang H-S, Zhu T, Wang X, Harper JF: Transcriptome changes for Arabidopsis in response to salt, osmotic, and cold stress. Plant Physiol 2002, 130(4):2129-2141.

3. Govind G, Harshavardhan V, Patricia J, Dhanalakshmi R, Senthil-Kumar M, Sreenivasulu N, Udayakumar M: Identification and functional validation of a unique set of drought induced genes preferentially expressed in response to gradual water stress in peanut. Mol Genet Genomics 2009, 281(6):607-607.

4. Haseneyer G, Schmutzer T, Seidel M, Zhou R, Mascher M, Schon C-C, Taudien S, Scholz U, Stein N, Mayer K, et al: From RNA-seq to large-scale genotyping - genomics resources for rye (Secale cereale L.). BMC Plant Biol 2011, $11(1): 131$.

5. Marques MC, Alonso-Cantabrana H, Forment J, Arribas R, Alamar S, Conejero V, Perez-Amador M: A new set of ESTs and cDNA clones from full-length and normalized libraries for gene discovery and functional characterization in citrus. BMC Genomics 2009, 10(1):428.

6. Bohnert HJ, Gong Q, Li P, Ma S: Unraveling abiotic stress tolerance mechanisms - getting genomics going. Curr Opin Plant Biol 2006, 9(2):180-188.

7. Bouchez D, Höfte H: Functional genomics in plants. Plant Physio/ 1998, 118(3):725-732.

8. Henikoff $S$, Comai L: Single-nucleotide mutations for plant functional genomics. Annu Rev Plant Biol 2003, 54(1):375-401

9. Krysan PJ, Young JC, Sussman MR: T-DNA as an insertional mutagen in Arabidopsis. Plant Cell 1999, 11(12):2283-2290.

10. Tadege M, Wen J, He J, Tu H, Kwak Y, Eschstruth A, Cayrel A, Endre G, Zhao PX, Chabaud M, et al: Large-scale insertional mutagenesis using the Tnt1 retrotransposon in the model legume Medicago truncatula. Plant J 2008, 54(2):335-347.

11. Gilchrist EJ, Haughn GW: TILLING without a plough: a new method with applications for reverse genetics. Curr Opin Plant Biol 2005, 8(2):211-215.
12. Travella S, Klimm TE, Keller B: RNA interference-based gene silencing as an efficient tool for functional genomics in hexaploid bread wheat. Plant Physiol 2006, 142(1):6-20.

13. Bouché N, Bouchez D: Arabidopsis gene knockout: phenotypes wanted. Curr Opin Plant Biol 2001, 4(2):111-117.

14. Lu R, Malcuit I, Moffett P, Ruiz MT, Peart J, Wu AJ, Rathjen JP, Bendahmane A, Day L, Baulcombe DC: High throughput virus-induced gene silencing implicates heat shock protein 90 in plant disease resistance. EMBO J 2003, 22(21):5690-5699.

15. Baulcombe DC: Fast forward genetics based on virus-induced gene silencing. Curr Opin Plant Biol 1999, 2(2):109-113.

16. Lu R, Martin-Hernandez AM, Peart JR, Malcuit I, Baulcombe DC: Virus-induced gene silencing in plants. Methods 2003, 30(4):296-303.

17. Dinesh-Kumar SP, Anandalakshmi R, Marathe R, Schiff M, Liu Y: Virus-induced gene silencing. Methods Mol Biol 2003, 236:287-294.

18. Senthil-Kumar M, Mysore KS: New dimensions for VIGS in plant functional genomics. Trends Plant Sci 2011, 16(12):656-665.

19. Liu Y, Schiff M, Dinesh-Kumar SP: Virus-induced gene silencing in tomato. Plant J 2002, 31(6):777-786.

20. Senthil-Kumar M, Rame Gowda HV, Hema R, Mysore KS, Udayakumar M: Virus-induced gene silencing and its application in characterizing genes involved in water-deficit-stress tolerance. J Plant Physiol 2008, 165(13):1404-1421.

21. George GM, van der Merwe MJ, Nunes-Nesi A, Bauer R, Fernie AR, Kossmann J, Lloyd JR: Virus-induced gene silencing of plastidial soluble inorganic pyrophosphatase impairs essential leaf anabolic pathways and reduces drought stress tolerance in Nicotiana benthamiana. Plant Physiol 2010, 154(1):55-66.

22. Ku H-M, Hu C-C, Chang H-J, Lin Y-T, Jan F-J, Chen C-T: Analysis by virus induced gene silencing of the expression of two proline biosynthetic pathway genes in Nicotiana benthamiana under stress conditions. Plant Physiol Bioch 2011, 49(10):1147-1154.

23. Guo $Y$, Huang $C$, Xie $Y$, Song $F$, Zhou $X$ : A tomato glutaredoxin gene SIGRX regulates plant responses to oxidative, drought and salt stresses. Planta 2010, 232(6):1499-1509.

24. Liang J, Deng G, Long H, Pan Z, Wang C, Cai P, Xu D, Nima Z-X, Yu M: Virus-induced silencing of genes encoding LEA protein in Tibetan hulless barley Hordeum vulgare ssp. vulgare and their relationship to drought tolerance. Mol Breed 2012, 30(1):441-451.

25. Catinot J, Buchala A, Abou-Mansour E, Métraux J-P: Salicylic acid production in response to biotic and abiotic stress depends on isochorismate in Nicotiana benthamiana. FEBS Lett 2008, 582(4):473-478.

26. Choi $\mathrm{H}$, Hwang $\mathrm{B}$ : The pepper extracellular peroxidase $\mathrm{CaPO} 2$ is required for salt, drought and oxidative stress tolerance as well as resistance to fungal pathogens. Planta 2012, 235(6):1369-1382.

27. Baena-Gonzalez E, Rolland F, Thevelein JM, Sheen J: A central integrator of transcription networks in plant stress and energy signalling. Nature 2007, 448(7156):938-942

28. Senthil-Kumar M, Mysore KS: Virus-induced gene silencing can persist for more than 2 years and also be transmitted to progeny seedlings in Nicotiana benthamiana and tomato. Plant Biotech J 2011, 9:797-806.

29. Lacomme C: Milestones in the development and applications of plant virus vector as gene silencing platforms. In Current Top Microbiology and Immunology. ; 2011:1-17.

30. Anand A, Vaghchhipawala Z, Ryu C-M, Kang L, Wang K, del-Pozo O, Martin GB, Mysore KS: Identification and characterization of plant genes involved in Agrobacterium-mediated plant transformation by virus-induced gene silencing. Mol Plant Microbe 2007, 20(1):41-52.

31. Hein I, Barciszewska-Pacak M, Hrubikova K, Williamson S, Dinesen M, Soenderby IE, Sundar S, Jarmolowski A, Shirasu K, Lacomme C: Virus-induced gene silencing-based functional characterization of genes associated with powdery mildew resistance in barley. Plant Physiol 2005, 138(4):2155-2164.

32. Senthil-Kumar M, Govind G, Kang L, Mysore K, Udayakumar M: Functional characterization of Nicotiana benthamiana homologs of peanut water deficit-induced genes by virus-induced gene silencing. Planta 2007, 225(3):523-539.

33. GENEVESTIGATOR database. https://www.genevestigator.com/gv/index.jsp.

34. Ryu C-M, Anand A, Kang L, Mysore KS: Agrodrench: a novel and effective agroinoculation method for virus-induced gene silencing in roots and diverse Solanaceous species. Plant J 2004, 40(2):322-331. 
35. Shi H, Ishitani M, Kim C, Zhu J-K: The Arabidopsis thaliana salt tolerance gene SOS1 encodes a putative $\mathrm{Na}+/ \mathrm{H}+$ antiporter. Proc Natl Acad Sci USA 2000, 97(12):6896-6901.

36. Wang J, Zhang $H$, Allen RD: Overexpression of an Arabidopsis peroxisomal ascorbate peroxidase gene in tobacco increases protection against oxidative stress. Plant Cell Physiol 1999, 40(7):725-732.

37. Roxas VP, Smith RK, Allen ER, Allen RD: Overexpression of glutathione S-transferase/glutathioneperoxidase enhances the growth of transgenic tobacco seedlings during stress. Nat Biotechnol 1997, 15(10):988-991.

38. Chang CCC, Ślesak I, Jordá L, Sotnikov A, Melzer M, Miszalski Z, Mullineaux PM, Parker JE, Karpińska B, Karpiński S: Arabidopsis chloroplastic glutathione peroxidases play a role in cross talk between photooxidative stress and immune responses. Plant Physiol 2009, 150(2):670-683.

39. Matsumura T, Tabayashi N, Kamagata Y, Souma C, Saruyama H: Wheat catalase expressed in transgenic rice can improve tolerance against low temperature stress. Physiol Plant 2002, 116(3):317-327.

40. Eltayeb AE, Kawano N, Badawi GH, Kaminaka H, Sanekata T, Morishima I, Shibahara T, Inanaga S, Tanaka K: Enhanced tolerance to ozone and drought stresses in transgenic tobacco overexpressing dehydroascorbate reductase in cytosol. Physiol Plant 2006, 127(1):57-65.

41. Yoshimura K, Miyao K, Gaber A, Takeda T, Kanaboshi H, Miyasaka $H_{\text {, }}$ Shigeoka S: Enhancement of stress tolerance in transgenic tobacco plants overexpressing chlamydomonas glutathione peroxidase in chloroplasts or cytosol. Plant J 2004, 37(1):21-33.

42. Deak M, Horvath GV, Davletova S, Torok K, Sass L, Vass I, Barna B, Kiraly Z, Dudits D: Plants ectopically expressing the ironbinding protein, ferritin, are tolerant to oxidative damage and pathogens. Nat Biotech 1999, 17(2):192-196.

43. Gurley WB: HSP101: a key component for the acquisition of thermotolerance in plants. Plant Cell 2000, 12(4):457-460.

44. Koizumi $\mathrm{N}$ : Isolation and responses to stress of a gene that encodes a luminal binding protein in Arabidopsis thaliana. Plant Cell Physiol 1996, 37(6):862-865

45. Kishor PBK, Hong Z, Miao G-H, Hu C-AA, Verma DPS: Overexpression of DELTA-1-pyrroline-5-carboxylate synthetase increases proline production and confers osmotolerance in transgenic plants. Plant Physiol 1995, 108(4):1387-1394

46. Albrecht V, Weinl S, Blazevic D, D'Angelo C, Batistic O, Kolukisaoglu Ü, Bock R, Schulz B, Harter K, Kudla J: The calcium sensor CBL1 integrates plant responses to abiotic stresses. Plant J 2003, 36(4):457-470.

47. Cheong YH, Kim K-N, Pandey GK, Gupta R, Grant JJ, Luan S: CBL1, a calcium sensor that differentially regulates salt, drought, and cold responses in Arabidopsis. Plant Cell 2003, 15(8):1833-1845.

48. Abe H, Urao T, Ito T, Seki M, Shinozaki K, Yamaguchi-Shinozaki K: Arabidopsis AtMYC2 (bHLH) and AtMYB2 (MYB) function as transcriptional activators in abscisic acid signaling. Plant Cell 2003, 15(1):63-78.

49. Chen $Y$, Ji F, Xie $H$, Liang J: Overexpression of the regulator of $\mathrm{G}$-protein signalling protein enhances ABA-mediated inhibition of root elongation and drought tolerance in Arabidopsis. J Exp Bot 2006, 57(9):2101-2110.

50. Ko J-H, Yang SH, Han K-H: Upregulation of an Arabidopsis RING-H2 gene, XERICO, confers drought tolerance through increased abscisic acid biosynthesis. Plant J 2006, 47(3):343-355.

51. Mauch-Mani B, Slusarenko AJ: Production of salicylic acid precursors is a major function of phenylalanine ammonia-lyase in the resistance of Arabidopsis to peronospora parasitica. Plant Cell 1996, 8(2):203-212.

52. Rogers EE, Ausubel FM: Arabidopsis enhanced disease susceptibility mutants exhibit enhanced susceptibility to several bacterial pathogens and alterations in PR-1 gene expression. Plant Cell 1997, 9(3):305-316.

53. Després $C$, Chubak C, Rochon A, Clark R, Bethune T, Desveaux D, Fobert PR: The Arabidopsis NPR1 disease resistance protein is a novel cofactor that confers redox regulation of DNA binding activity to the basic domain/leucine zipper transcription factor TGA1. Plant Cell 2003, 15(9):2181-2191.

54. Tornero P, Merritt P, Sadanandom A, Shirasu K, Innes RW, Dangl JL: RAR1 and NDR1 contribute quantitatively to disease resistance in Arabidopsis, and their relative contributions are dependent on the $\mathrm{R}$ gene assayed. Plant Cell 2002, 14(5):1005-1015.

55. Grant JJ, Chini A, Basu D, Loake GJ: Targeted activation tagging of the Arabidopsis NBS-LRR gene, ADR1, conveys resistance to virulent pathogens. Mol Plant Microbe In 2003, 16(8):669-680.
56. Watanabe N, Lam E: Arabidopsis metacaspase $2 \mathrm{~d}$ is a positive mediator of cell death induced during biotic and abiotic stresses. Plant J 2011, 66(6):969-982

57. Liu Y, Schiff M, Dinesh-Kumar SP: Involvement of MEK1 MAPKK NTF6 MAPK, WRKY/MYB transcription factors, COI1 and CTR1 in $\mathrm{N}$-mediated resistance to tobacco mosaic virus. Plant J 2004, 38(5):800-809

58. Geraats BPJ, Bakker PAHM, Lawrence CB, Achuo EA, Höfte M, van Loon LC: Ethylene-insensitive tobacco shows differentially altered susceptibility to different pathogens. Phytopathology 2003, 93(7):813-821.

59. Verhoeyen ME, Bovy A, Collins G, Muir S, Robinson S, de Vos CHR, Colliver S: Increasing antioxidant levels in tomatoes through modification of the flavonoid biosynthetic pathway. J Exp Bot 2002, 53(377):2099-2106.

60. Verslues PE, Agarwal M, Katiyar-Agarwal S, Zhu J, Zhu J-K: Methods and concepts in quantifying resistance to drought, salt and freezing, abiotic stresses that affect plant water status. Plant J 2006, 45(4):523-539.

61. Ji W, Zhu Y, Li Y, Yang L, Zhao X, Cai H, Bai X: Over-expression of a glutathione S-transferase gene, GsGST, from wild soybean (Glycine soja) enhances drought and salt tolerance in transgenic tobacco. CORD Conference Proceedings 2010, 32(8):1173-1179.

62. Shin D, Moon S-J, Han S, Kim B-G, Park SR, Lee S-K, Yoon H-J, Lee HE, Kwon H-B, Baek D, et al: Expression of StMYB1R-1, a novel potato single MYB-like domain transcription factor, increases drought tolerance. Plant Physiol 2011, 155(1):421-432.

63. Falk A, Feys BJ, Frost LN, Jones JDG, Daniels MJ, Parker JE: EDS1, an essential component of $\mathrm{R}$ gene-mediated disease resistance in Arabidopsis has homology to eukaryotic lipases. Proc Natl Acad Sci USA 1999, 96(6):3292-3297.

64. Chini A, Grant JJ, Seki M, Shinozaki K, Loake GJ: Drought tolerance established by enhanced expression of the CC-NBS-LRR gene, ADR1, requires salicylic acid, EDS1 and ABI1. Plant J 2004, 38(5):810-822.

65. Xing $Y$, Jia W, Zhang J: AtMEK1 mediates stress-induced gene expression of CAT1 catalase by triggering $\mathrm{H} 2 \mathrm{O} 2$ production in Arabidopsis. J Exp Bot 2007, 58(11):2969-2981.

66. Wang Y, Wang T, Li K, Li X: Genetic analysis of involvement of ETR1 in plant response to salt and osmotic stress. Plant Growth Regul 2008, 54(3):261-269.

67. Jiang W, YU D: Arabidopsis WRKY2 transcription factor mediates seed germination and postgermination arrest of development by abscisic acid. BMC Plant Biol 2009, 9(1):96.

68. Ganesan G, Sankararamasubramanian HM, Harikrishnan M, Ashwin G, Parida A: A MYB transcription factor from the grey mangrove is induced by stress and confers $\mathrm{NaCl}$ tolerance in tobacco. J Exp Bot 2012, 63(12):4549-4561.

69. Parida AK, Das AB: Salt tolerance and salinity effects on plants: a review. Ecotoxi Environ Safe 2005, 60(3):324-349.

70. Matsuoka D, Nanmori T, Sato K, Fukami Y, Kikkawa U, Yasuda T: Activation of AtMEK1, an Arabidopsis mitogen-activated protein kinase kinase, in vitro and in vivo: analysis of active mutants expressed in E. coli and generation of the active form in stress response in seedlings. Plant J 2002, 29(5):637-647.

71. Silva-Ortega CO, Ochoa-Alfaro AE, Reyes-Agüero JA, Aguado-Santacruz GA, Jiménez-Bremont JF: Salt stress increases the expression of p5cs gene and induces proline accumulation in cactus pear. Plant Physiol Biochem 2008, 46(1):82-92.

72. Yang $L, Z u$ Y-G, Tang Z-H: Ethylene improves Arabidopsis salt tolerance mainly via retaining $\mathrm{K}+$ in shoots and roots rather than decreasing tissue $\mathrm{Na}+$ content. Environ Exp Bot 2013, 86:60-69.

73. Tripathy JN, Zhang J, Robin S, Nguyen TT, Nguyen HT: QTLs for cell-membrane stability mapped in rice (Oryza sativa L.) under drought stress. Theor Appl Genet 2000, 100(8):1197-1202.

74. Katiyar-Agarwal S, Agarwal M, Grover A: Heat-tolerant basmati rice engineered by over-expression of hsp101. Plant Mol Biol 2003 51(5):677-686

75. Murgia I, Tarantino D, Vannini C, Bracale M, Carravieri S, Soave C: Arabidopsis thaliana plants overexpressing thylakoidal ascorbate peroxidase show increased resistance to Paraquat-induced photooxidative stress and to nitric oxide-induced cell death. Plant J 2004, 38(6):940-953.

76. Mhamdi A, Queval G, Chaouch S, Vanderauwera S, Van Breusegem F Noctor G: Catalase function in plants: a focus on Arabidopsis mutants as stress-mimic models. J Exp Bot 2010, 61(15):4197-4220. 
77. Lee YP, Kim SH, Bang JW, Lee HS, Kwak SS, Kwon SY: Enhanced tolerance to oxidative stress in transgenic tobacco plants expressing three antioxidant enzymes in chloroplasts. Plant Cell Rep 2007, 26(5):591-598,

78. Katiyar-Agarwal S, Zhu J, Kim K, Agarwal M, Fu X, Huang A, Zhu JK: The plasma membrane $\mathrm{Na}+/ \mathrm{H}+$ antiporter SOS1 interacts with RCD1 and functions in oxidative stress tolerance in Arabidopsis. Proc Natl Acad SCi USA 2006, 103(49):18816-18821.

79. Kim M, Lee U, Small I, des Francs-Small CC, Vierling E: Mutations in an Arabidopsis mitochondrial transcription termination factor-related protein enhance thermotolerance in the absence of the major molecular chaperone HSP101. Plant Cell 2012, 24(8):3349-3365.

80. Székely G, Abrahám E, Cséplo A, Rigó G, Zsigmond L, Csiszár J, Ayaydin F, Strizhov N, Jásik J, Schmelzer E, et al: Duplicated P5CS genes of Arabidopsis play distinct roles in stress regulation and developmental control of proline biosynthesis. Plant J 2008, 53(1):11-28

81. Guo J, Pang Q, Wang L, Yu P, Li N, Yan X: Proteomic identification of MYC2-dependent jasmonate-regulated proteins in Arabidopsis thaliana. Proteome Sci 2012, 10(1):57.

82. Huang J, Gu M, Lai Z, Fan B, Shi K, Zhou YH, Yu JQ, Chen Z: Functional analysis of the Arabidopsis PAL gene family in plant growth, development, and response to environmental stress. Plant Physiol 2010, 153(4):1526-1538.

83. Bashandy T, Taconnat L, Renou JP, Meyer Y, Reichheld JP: Accumulation of flavonoids in an ntra ntrb mutant leads to tolerance to UV-C. Mol Plant 2009, 2(2):249-258

84. Atkinson NJ, Urwin PE: The interaction of plant biotic and abiotic stresses: from genes to the field. J Exp Bot 2012, 63(10):3523-3543.

85. Wang K, Kang L, Anand A, Lazarovits G, Mysore KS: Monitoring in planta bacterial infection at both cellular and whole-plant levels using the green fluorescent protein variant GFPuv. New Phytol 2007, 174(1):212-223.

86. Wang K, Senthil-Kumar M, Ryu C-M, Kang L, Mysore KS: Phytosterols play a key role in plant innate immunity against bacterial pathogens by regulating nutrient efflux into the apoplast. Plant Physiol 2012, 158(4):1789-1802.

87. Dean JD, Goodwin PH, Hsiang T: Induction of glutathione S-transferase genes of Nicotiana benthamiana following infection by Colletotrichum destructivum and $C$. orbiculare and involvement of one in resistance. J Exp Bot 2005, 56(416):1525-1533.

88. Gao F, Shu X, Ali M, Howard S, Li N, Winterhagen P, Qiu W, Gassmann W: A functional EDS1 ortholog is differentially regulated in powdery mildew resistant and susceptible grapevines and complements an Arabidopsis eds1 mutant. Planta 2010, 231(5):1037-1047.

89. Tuba Z, Lichtenthaler HK, Csintalan Z, Nagy Z, Szente K: Loss of chlorophylls, cessation of photosynthetic $\mathrm{CO} 2$ assimilation and respiration in the poikilochlorophyllous plant Xerophyta scabrida during desiccation. Physiol Plant 1996, 96(3):383-388

90. Maathuis FJM, Amtmann $\mathrm{A}: \mathrm{K}+$ nutrition and $\mathrm{Na}+$ toxicity: The basis of cellular K+/Na + ratios. Ann Bot 1999, 84(2):123-133.

91. Mittal S, Kumari N, Sharma V: Differential response of salt stress on brassica juncea: photosynthetic performance, pigment, proline, D1 and antioxidant enzymes. Plant Physiol Bioch 2012, 54:17-26.

92. OlíAs R, Eljakaoui Z, Li JUN, De Morales PA, MaríN-Manzano MC, Pardo JM, Belver A: The plasma membrane $\mathrm{Na}+/ \mathrm{H}+$ antiporter SOS1 is essential for salt tolerance in tomato and affects the partitioning of $\mathrm{Na}+$ between plant organs. Plant Cell Environ 2009, 32(7):904-916.

93. Hong S-W, Lee U, Vierling E: Arabidopsis hot mutants define multiple functions required for acclimation to high temperatures. Plant Physiol 2003, 132(2):757-767.

94. Queitsch C, Hong S-W, Vierling E, Lindquist S: Heat shock protein 101 plays a crucial role in thermotolerance in Arabidopsis. Plant Cell 2000, 12(4):479-492

95. Nieto-Sotelo J, Martínez LM, Ponce G, Cassab Gl, Alagón A, Meeley RB, Ribaut J-M, Yang R: Maize HSP101 plays important roles in both induced and basal thermotolerance and primary root growth. Plant Cell 2002, 14(7):1621-1633

96. Senthil-Kumar M, Srikanthbabu V, Mohan Raju B, Kumar G, Shivaprakash N, Udayakumar M: Screening of inbred lines to develop a thermotolerant sunflower hybrid using the temperature induction response (TIR) technique: a novel approach by exploiting residual variability. J Exp Bot 2003, 54(392):2569-2578
97. Zhang $X$, Wang $L$, Meng $H$, Wen $H$, Fan $Y$, Zhao J: Maize ABP9 enhances tolerance to multiple stresses in transgenic Arabidopsis by modulating ABA signaling and cellular levels of reactive oxygen species. Plant $\mathrm{Mol}$ Biol 2011, 75(4):365-378.

98. Xiong $L$, Yang $Y$ : Disease resistance and abiotic stress tolerance in rice are inversely modulated by an abscisic acid-inducible mitogen-activated protein kinase. Plant Cell 2003, 15(3):745-759.

99. Xu P, Zhang Y, Kang L, Roossinck MJ, Mysore KS: Computational estimation and experimental verification of off-target silencing during posttranscriptional gene silencing in plants. Plant Physiol 2006, 142(2):429-440.

100. Patade VY, Bhargava S, Suprasanna P: Effects of $\mathrm{NaCl}$ and iso-osmotic PEG stress on growth, osmolytes accumulation and antioxidant defense in cultured sugarcane cells. Plant Cell Tiss Org 2012, 108(2):279-286.

101. Huguet-Robert V, Sulpice R, Lefort C, Maerskalck V, Emery N, Larher FR: The suppression of osmoinduced proline response of Brassica napus $L$. var oleifera leaf discs by polyunsaturated fatty acids and methyl-jasmonate. Plant Sci 2003, 164(1):119-127.

102. Sanan-Mishra N, Pham XH, Sopory SK, Tuteja N: Pea DNA helicase 45 overexpression in tobacco confers high salinity tolerance without affecting yield. Proc Natl Acad Sci U S A 2005, 102(2):509-514.

103. Ramegowda V, Senthil-Kumar M, Nataraja KN, Reddy MK, Mysore KS, Udayakumar M: Expression of a finger millet transcription factor, ECNAC1 in tobacco confers abiotic stress-tolerance. PLOS ONE 2012, 7(7):e40397.

\section{doi:10.1186/1471-2229-13-193}

Cite this article as: Ramegowda et al:: A high-throughput virus-induced gene silencing protocol identifies genes involved in multi-stress tolerance. BMC Plant Biology 2013 13:193.

\section{Submit your next manuscript to BioMed Central and take full advantage of:}

- Convenient online submission

- Thorough peer review

- No space constraints or color figure charges

- Immediate publication on acceptance

- Inclusion in PubMed, CAS, Scopus and Google Scholar

- Research which is freely available for redistribution 